\title{
Magmatic processes revealed by textural and compositional trends in Merapi dome lavas
}

\author{
J.E. Hammer ${ }^{\mathrm{a}, *}$, K.V. Cashman, B. Voight \\ ${ }^{a}$ Department of Geological Sciences, 1272 University of Oregon, Eugene, OR 97403-1272, USA \\ ${ }^{\mathrm{b}}$ Department of Geosciences, Pennsylvania State University, 303 Deike Building, University Park, PA 16802-2712, USA
}

\begin{abstract}
Syn-eruptive degassing of volcanoes may lead to syn-eruptive crystallization of groundmass phases. We have investigated this process using textural and compositional analysis of dome material from Merapi volcano, Central Java, Indonesia. Samples included dome lavas from the 1986-88, 1992-93, 1994 and 1995 effusive periods as well as pyroclastic material deposited by the November 1994 dome collapse. With total crystallinities commonly in excess of 70\% (phenocrysts + microlites), the liquids present in Merapi andesites are highly evolved (rhyolitic) at the time of eruption. Feldspar microlites in dome rocks consist of plagioclase cores $\left(\mathrm{Ab}_{63} \mathrm{An}_{29} \mathrm{Or}_{8}\right)$ surrounded by alkali feldspar rims $\left(\mathrm{Ab}_{53} \mathrm{An}_{5} \mathrm{Or}_{42}\right)$, compositional pairs which are not in equilibrium. A change in the phase relations of the ternary feldspar system caused by degassing best explains the observed transition in feldspar composition. A small proportion of highly vesicular airfall tephra grains from the 1994 collapse have less evolved glass compositions than typical dome material and contain rimless plagioclase microlites, suggesting that the 1994 collapse event incorporated less-degassed, partially liquid magma in addition to fully solidified dome rock.

As decompression drives volatile exsolution, rates of degassing and resultant microlite crystallization may be governed by magma ascent rate. Microlite crystallinity is nearly identical among the 1995 dome samples, an indication that similar microlite growth conditions $\left(P_{\mathrm{H}_{2}} \mathrm{O}\right.$ and temperature) were achieved throughout this extrusive period. However, microlite number density varied by more than a factor of four in these samples, and generally increased with distance from the vent. Low vent-ward microlite number densities and greater microlite concentrations down-flow probably reflect progressively decreasing rates of undercooling at the time of crystal nucleation during extrusion of the 1995 dome. Comparison between dome extrusion episodes indicates a correlation between lava effusion rate and microlite number density, suggesting that extrusion slowed during 1995. Crystal textures and compositions in the 1992-93 and 1994 domes share the range exhibited by the 1995 dome, suggesting that transitions in crystallization conditions (i.e., rates of undercooling determined by effusion rate) are cyclic. (C) 2000 Elsevier Science B.V. All rights reserved.
\end{abstract}

Keywords: degassing; lava dome; feldspar group; microlites; crystal textures

\section{Introduction}

Two important issues related to the mitigation of

* Corresponding author. Present address: Department of Geological Sciences, Brown University Box 1846, Providence, RI 02912-1846, USA. Tel.: +1 401 863-1383; fax: +1 401 863-2058.

E-mail address: jhammer@brown.edu (J.E. Hammer). hazards associated with dome-forming eruptions are: (1) the nature of transitions in eruptive style between effusion and explosion; and (2) assessment of the extent to which magmatic processes are involved in dome collapse. Addressing both of these topics involves understanding processes of volatile exsolution and escape during magma ascent (Woods and Koyaguchi, 1994; Barclay et al., 1995; Bagdassarov 
et al., 1996; Stasiuk et al., 1996). When magma degasses as an open system during ascent it arrives at the surface non-explosively (Westrich et al., 1988; Fink et al., 1992; Stix et al., 1993). However, blockage of escaping gases (partly closed system degassing) may cause the style of eruption to abruptly become explosive (Fink and Kieffer, 1993; Nakada, 1993; Zapata et al., 1997).

Approaches to the study of degassing at active volcanoes include direct gas sampling or flux measurements (Le Guern et al., 1982; Stoiber et al., 1983; Rose et al., 1988; Zapata et al., 1997) and interpretation of long-period seismicity thought to be associated with unsteady fluid movement (Chouet, 1996; Cruz and Chouet, 1997). In addition, volatile and isotopic studies of glasses and melt inclusions in the dome rocks themselves have yielded information about the magnitude of pre- and syn-eruptive degassing and the sealed (closed) vs. leaky (open) system nature of this process (Taylor et al., 1983; Newman et al., 1988; Anderson and Fink, 1989; Fink et al., 1992). However, these measurements reflect the integrated sum of degassing events, so that the conduit processes of consequence to eruptive style may be overprinted by post-eruptive outgassing. Another investigative tool is the characterization and analysis of crystal textures which record conditions of gas loss (Swanson et al., 1989; Cashman, 1992; Stevenson et al., 1994a). Because the liquidus temperature rises in response to decreasing $\mathrm{H}_{2} \mathrm{O}$ content, the extent of degassing may be reflected in the groundmass (microlite) crystallinity of the quenched magma provided that crystals have sufficient time to grow (Geschwind and Rutherford, 1995). The spatial concentration of microlites is a reflection of the effective supersaturation rate, so that rapid rates of undercooling result in high rates of nucleation and a dense population of crystals (Swanson, 1977). Crystal morphology may also constrain rates and extents of undercooling (Lofgren, 1974; Corrigan, 1982; Sunagawa, 1984). Furthermore, the composition of crystallizing feldspar is dependent on $\mathrm{H}_{2} \mathrm{O}$ content as well as the liquid composition (Abbot, 1978; Housh and Luhr, 1991; Nekvasil, 1992; Geschwind and Rutherford, 1995). Systematic variation in feldspar composition may indicate a change in the extent of degassing over time, while textural parameters such as crystal number density may signal changes in the rate at which degassing occurs.
In this study we examine microlites in recent dome lavas and pyroclastic deposits of Merapi volcano, Indonesia. In contrast to more vigorous, sporadic dome-producing eruptions at Mt. Unzen, Japan, and Soufriere Hills, Montserrat, Merapi is characterized by long-lived slow effusion and regular dome collapses interrupted by periodic ( $\sim 50 \mathrm{y}$ intervals; van Bemmelen, 1949) explosive eruptions. Evaluation of the controls on transitions in eruptive style is a particularly timely concern at Merapi given that the last large explosive eruption occurred in 1930. Samples from the 1986-88, 1992-93, 1994 and 1995 domes as well as pyroclastic flow, surge and airfall material from the November 22, 1994 collapse were included in a comparative analysis of groundmass microlite characteristics. Feldspar composition and microlite number density, shape and size distributions were characterized with the goal of exploring the extent to which microlites record the process of degassing at Merapi.

\section{Recent merapi activity}

During the last $20 \mathrm{y}$, episodes of dome growth and failure have reshaped the SW-facing crater summit of Merapi. A brief summary of activity in Table 1 provides a context for the samples characterized in this study (unpublished data, Merapi Volcano Observatory; Ratdomopurbo, 1995). The current dome complex began to form after the catastrophic dome collapse of June 13-15, 1984. Three main periods of activity can be identified through 1995: (1) construction of the 1984-90 dome, with the major growth periods between June 1984 through February 1985 and resurgence from October 1986 through mid1988; (2) vigorous effusion of a new dome, 1992 through mid-1993; and (3) effusion from a new vent, 1994-95, with main growth episodes between April and August 1994. Resurgence from the same vent following the November 1994 collapse began in July 1995. The pre- and post-collapse segments of the 1994-95 effusive period are hereafter identified as the 1994 and 1995 domes, respectively. Volume surveys demonstrate that over this period effusive flux varied by a factor of six, ranging from 0.05 to $0.32 \mathrm{~m}^{3} \mathrm{~s}^{-1}$. Long term effusion rate is relatively constant at $0.039 \mathrm{~m}^{3} \mathrm{~s}^{-1}(100 \mathrm{y}$ average, 
Table 1

Recent Merapi activity and samples used in this study (gray arrows indicate nueés aredentes; black arrows indicate catastrophic dome failure events)

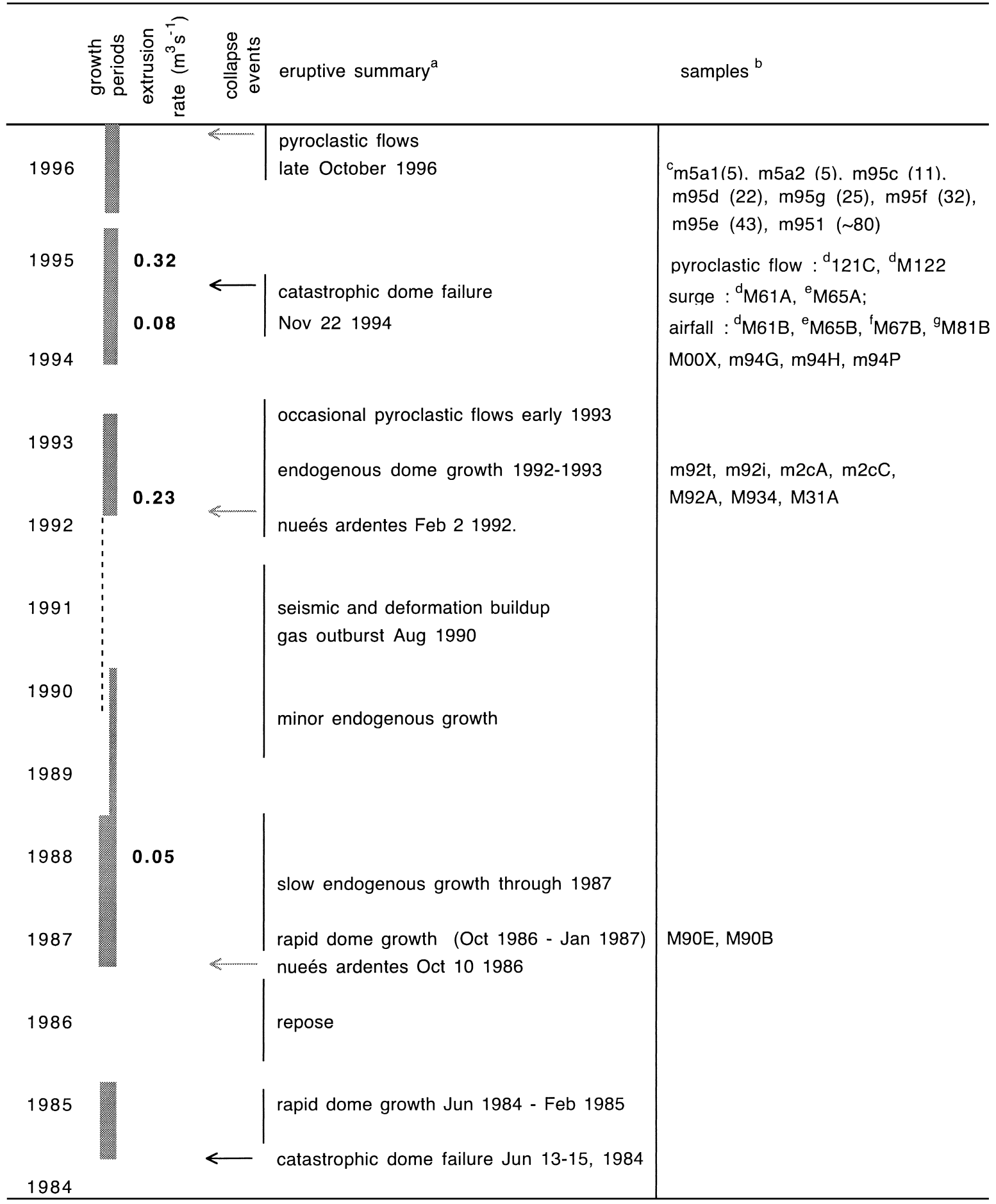


Siswowidjoyo et al., 1995). Although this extrusion rate is slow compared with the range in growth rates of Mount St. Helens dome lobes $\left(0.7-20 \mathrm{~m}^{3} \mathrm{~s}^{-1}\right.$; Anderson et al., 1995) and the early 1991 Unzen extrusion $\left(4.6 \mathrm{~m}^{3} \mathrm{~s}^{-1}\right.$; Nakada and Motomura, 1995), the continuous nature of this activity has produced a total volume of lava during the last $100 \mathrm{y}$ of more than $10^{8} \mathrm{~m}^{3}$ (Siswowidjoyo et al., 1995).

Rock falls and pyroclastic flows occur frequently at Merapi. Pyroclastic flows may transport material more than $10 \mathrm{~km}$ from the vent, sometimes maintaining temperatures above $300^{\circ} \mathrm{C}$ at the time of deposition (Berthommier, 1990; Boudon et al., 1993). A catastrophic dome failure mobilized roughly $2.5-3 \times 10^{6} \mathrm{~m}^{3}$ of pyroclastic debris in November 1994 , producing pyroclastic flows and surges that claimed at least 64 lives in the villages of Turgo and Kaliurang, about $5 \mathrm{~km}$ from the summit (Smithsonian, 1995; Abdurachman et al., 2000 - this volume). Several episodes of dome destruction, such as the June 1984 and February 1992 pyroclastic flows, have occurred at the beginning of growth periods. Others, including the November 1994 failure and pyroclastic flows in October 1996, happen within eruptive intervals. During the $10 \mathrm{y}$ interval investigated here, no significant collapses occurred during the relatively quiet intervals of 1988-92 and mid1993-94 (Ratdomopurbo, 1995).

Merapi is also recognized for consistent production of magmatic gases uncontaminated by meteoric fluids (Le Guern et al., 1982; Symonds et al., 1987). Allard et al. (1995) estimate that the mass flux of magmatic gases from Merapi exceeds the mass flux of lava from the volcano, indicating that degassing occurs at depth from un-erupted lava. Using measurements of the long-term $\mathrm{SO}_{2}$ gas flux and original magmatic sulfur content, Allard et al. (1995) calculate that an average of $1.3 \times 10^{5} \mathrm{~m}^{3}$ of magma is degassed per day, $\sim 40$ times greater than the 100-year average mass of magma extruded per day.

\section{Sampling}

Samples from the 1986-98 portion of the 1986-90 dome, and from the 1992-93, 1994-95, and 1995 effusive episodes were collected in 1990, 1992,
1993, and 1995 (Fig. 1). Sample M92A was collected in June 1992 from the 1992 dome; other samples of the 1992-93 dome were obtained in 1993 or 1995. Samples collected before 1993 were fragments of blocky lava collected during monitoring work, during a period of dominantly endogenous dome growth. Although the relative ages of samples are incompletely constrained, these samples do provide a basis for comparison between flows. Several additional samples of the 1992-93 lava and 1994 portion of the 1994-95 dome were collected in late 1995. Samples from the 1992-93 dome were collected in situ from the northwestern part of the crater. Samples of the 1994 dome were collected from blocks that toppled from the dome onto a shelf on the southern part of the crater rim near the Gendol solfatara field (Le Guern et al., 1982) before November 22, 1994, as well as in situ samples from the 1994 dome headwall that remained following the November dome collapse. Pyroclastic flow, surge, and airfall material deposited by the November 22, 1994 nuée ardente was collected from the Boyong river valley at locations $5-6 \mathrm{~km}$ from the vent. The airfall deposit was generated as an ash cloud from the pyroclastic flow in the Boyong channel. These particulate materials represent a sampling from the interior of the dome at the time of collapse.

Relatively straightforward access to the dome in October 1995 provided an excellent opportunity to sample the 1995 dome in detail. Samples were collected at 5-10 m intervals along a linear trend extending down-flow from the vent of 1995 lava (Fig. 1). All samples were taken from a single coherent slab of lava, except for sample 951 which was collected with the assistance of the Merapi Volcano Observatory staff approximately $80 \mathrm{~m}$ from the vent (Table 1).

\section{Analytical methods}

\subsection{Compositional analyses}

A CAMECA SX-50 Electron Probe Microanalyzer (EPMA) utilizing a ZAF X-ray intensity reduction routine was used to determine glass and plagioclase microlite compositions. Powdered whole rock samples from several domes were also analyzed by 


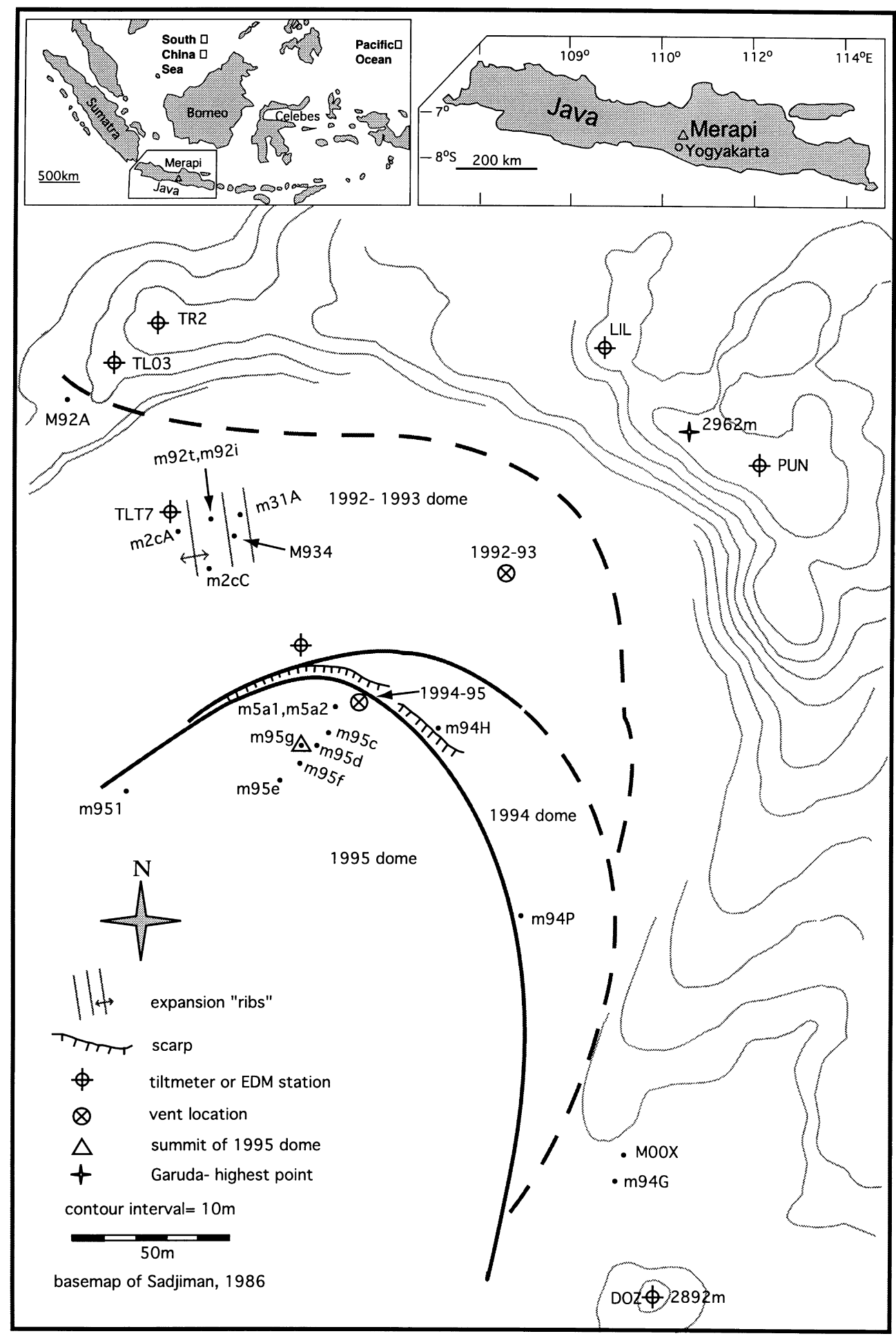

Fig. 1. Summit map showing locations of dome samples used in this study. Features of the inactive part of the summit were obtained from the topographic map of Sadjiman, (1986). Inset maps modified from Boudon et al., 1993. 
EPMA following fusion at $1200^{\circ} \mathrm{C}$ for $2 \mathrm{~h}$ in a Del-Tec one atmosphere furnace. Feldspar analyses were obtained using a focused beam with a $15 \mathrm{keV}$ accelerating voltage and $10 \mathrm{nA}$ beam current. Plagioclase microlite and phenocryst compositions were determined for the 1995 dome samples and several grains from the airfall, pyroclastic flow, and surge deposits from the 1994 collapse.

Glass analyses were obtained using $15 \mathrm{keV}$ accelerating voltage and $10 \mathrm{nA}$ beam current. A defocused beam (3-5 $\mu \mathrm{m}$ spot size) was used to minimize alkali loss. Sodium was counted first to further reduce the effect of migration away from the beam. Synthetic glass standards were used for measuring $\mathrm{Al}, \mathrm{Si}, \mathrm{Fe}$, $\mathrm{Mn}, \mathrm{Ca}$, and $\mathrm{Mg}$ to best match the atomic configuration and abundance of these elements in the samples. The rate of sodium loss from the glasses was assessed by applying a defocused beam ( $6 \mu \mathrm{m}$ diameter) to the largest available expanses of glass for periods of $60 \mathrm{~s}$, while the instrument counted $\mathrm{NaK}_{\alpha} \mathrm{X}$-rays. The intensity of the signal decreased linearly as a function of time. Based on extrapolation to zero time, we calculated a $12 \%$ loss in $\mathrm{Na}$ over the first $10 \mathrm{~s}$, the length of time during which $\mathrm{Na}$ is counted during analyses. A multiplicative factor of 1.12 has been applied to all the measurements of $\mathrm{Na}_{2} \mathrm{O}$ in glass reported in Table 2.

\subsection{Textural analyses}

A standard petrographic microscope was used at low magnifications $(25-50 \times)$ for initial sample characterization. Polished, carbon-coated thin sections were subsequently imaged with a JEOL 6300V Scanning Electron Microscope. Conditions for imaging with back-scattered electrons (BSE) include $10 \mathrm{keV}$ acceleration potential and 3-6 nA beam current, operating at $15 \mu \mathrm{m}$ working distance. Most crystallinity and crystal number density measurements were made using images collected at $1000 \times$ magnification. Lower magnification $(500 \times)$ was used to characterize samples having relatively large microlites. Measurements of crystal dimensions and areas, phenocryst-free groundmass crystallinity, and microlite number density, were made using two image processing software packages, NIH Image and Dapple PrismView. Only groundmass textures were characterized, thus all terms describing crystal textures refer to microlite features unless phenocrysts are explicitly discussed. For example, crystallinity refers to the feldspar microlite content of the groundmass.

The average atomic number of plagioclase microlites is typically very close to that of the glass, so that the contrast between these phases in a (BSE) grayscale image is insufficient to resolve the microlites by gray scale value alone. For this reason, microlites were identified and selected manually. Each crystal was marked with a dot of a particular gray value. The dots were then selected and counted automatically (see Fig. 2a). The phenocryst-free area of each image represents the area of liquid available for late stage crystallization, and is called the reference area $\left(A_{\mathrm{R}}\right)$. Crystal number density $\left(N_{\mathrm{A}}\right)$, or number of microlites per $\mathrm{mm}^{2}$, is obtained by dividing the number of crystals in an image not including those intersecting two of the four image edges (Rose, 1988) by the reference area. Crystallinity, expressed as a fraction $(\phi)$ of the groundmass, was measured by point-counting microlites from printed versions of the images. All symbols used are defined in Appendix A.

To obtain shape and size information about individual crystals in an image, each plagioclase microlite was manually outlined using NIH Image. Outlined features were selected, filled in, and converted into a binary image. Similar binary images were made for vesicles and phenocrysts, and combined using Boolean operations to create a graphical map of the original gray scale image where each component of interest (e.g. microlites, vesicles, glass, phenocrysts) is represented by a different gray value (Fig. 2b). Only crystals that were completely enclosed within the image were used to obtain size and shape information.

Assuming that crystals are square in twodimensional (2D) intersections, an average crystal size $\left(s_{n}\right)$ can be computed based on the number of crystals and their total area: $s_{n}=\left[\left(\phi A_{\mathrm{R}}\right) /\right.$ (number of microlites) $]^{0.5}$, or $\left(\phi / N_{\mathrm{A}}\right)^{0.5}$. Although this parameter is a convenient means for comparing samples, size distribution and shape information obtained from select samples also allows average three-dimensional (3D) sizes to be computed. Additionally, a volume-based median size $\left(s_{\mathrm{v}}\right)$, obtained from the cumulative volume distribution, allows estimation of a characteristic size on the basis of volume (and therefore mass) rather than number. However, all volume-based estimates of 
Table 2

Compositions of Merapi glasses

\begin{tabular}{|c|c|c|c|c|c|c|c|c|c|}
\hline \multicolumn{10}{|l|}{ Domes } \\
\hline \multirow{3}{*}{ Sample } & \multicolumn{6}{|c|}{ This study: 1995 dome } & \multirow{4}{*}{$\frac{\text { Bardintzeff, } 1984}{1978 \text { dome }^{\text {b }}}$} & \multirow{2}{*}{\multicolumn{2}{|c|}{$\begin{array}{l}\text { Berthommier, } 1990 \\
1984 \text { dome }^{\text {b }}\end{array}$}} \\
\hline & $\mathrm{m} 95 \mathrm{a} 1^{\mathrm{a}}$ & $\mathrm{m} 95 \mathrm{c}^{\mathrm{a}}$ & $\mathrm{m} 95 \mathrm{~d}^{\mathrm{a}}$ & $\mathrm{m} 95 \mathrm{~g}^{\mathrm{a}}$ & $\mathrm{m} 95 \mathrm{e}^{\mathrm{a}}$ & $\mathrm{m} 951^{\mathrm{a}}$ & & & \\
\hline & \multicolumn{6}{|c|}{ Increasing distance from vent $\longrightarrow$} & & Light $^{\mathrm{c}}$ & $\operatorname{Dark}^{\mathrm{c}}$ \\
\hline$n$ & 8 & 5 & 8 & 4 & 2 & 3 & & 2016 & 252 \\
\hline $\mathrm{SiO}_{2}$ & $74.3(0.4)$ & $75.3(0.4)$ & $74.5(0.4)$ & $75.7(0.6)$ & $74.6(0.3)$ & $75.2(1.2)$ & 75.0 & 71.7 & 74.5 \\
\hline $\mathrm{TiO}_{2}$ & $0.43(0.13)$ & $0.48(0.08)$ & $0.42(0.07)$ & $0.44(0.14)$ & $0.52(0.09)$ & $0.38(0.05)$ & 0.48 & 0.44 & 0.50 \\
\hline $\mathrm{Al}_{2} \mathrm{O}_{3}$ & $12.6(0.1)$ & $12.4(0.2)$ & $11.8(0.4)$ & $12.6(0.3)$ & $12.3(0.1)$ & $12.5(0.4)$ & 12.9 & 14.7 & 13.4 \\
\hline $\mathrm{MgO}$ & $0.18(0.03)$ & $0.17(0.03)$ & $0.16(0.03)$ & $0.11(0.01)$ & $0.14(0.04)$ & $0.07(0.01)$ & 0.21 & 0.26 & 0.12 \\
\hline $\mathrm{CaO}$ & $0.49(0.08)$ & $0.51(0.13)$ & $0.51(0.07)$ & $0.58(0.08)$ & $0.54(0.05)$ & $0.50(0.09)$ & 0.42 & 0.79 & 0.32 \\
\hline $\mathrm{MnO}$ & $0.09(0.02)$ & $0.10(0.05)$ & $0.11(0.02)$ & $0.07(0.03)$ & $0.02(0.01)$ & $0.07(0.06)$ & 0.08 & 0.20 & 0.07 \\
\hline $\mathrm{FeO}_{\mathrm{T}}$ & $2.52(0.24)$ & $2.35(0.14)$ & $2.43(0.19)$ & $2.10(0.07)$ & $2.24(0.11)$ & $1.57(0.22)$ & 1.78 & 2.35 & 2.19 \\
\hline $\mathrm{Na}_{2} \mathrm{O}$ & $3.79(0.21)$ & $3.50(0.41)$ & $3.08(0.22)$ & $3.31(0.22)$ & $3.65(0.04)$ & $3.69(0.16)$ & 2.95 & 3.44 & 2.65 \\
\hline $\mathrm{K}_{2} \mathrm{O}$ & $6.02(0.13)$ & $5.92(0.30)$ & $5.59(0.26)$ & $6.09(0.08)$ & $5.98(0.21)$ & $6.21(0.22)$ & 6.13 & 6.10 & 6.20 \\
\hline Total & $100.4(0.5)$ & $100.7(0.4)$ & $98.8(0.4)$ & $101.0(0.3)$ & $99.9(0.4)$ & $100.2(0.8)$ & 100.0 & 100.0 & 100.0 \\
\hline \multicolumn{10}{|l|}{ Tephra } \\
\hline \multirow{3}{*}{ Sample } & \multicolumn{6}{|c|}{ This study: airfall material from November 1994 collapse } & Bardintzeff, 1984 & & \\
\hline & $\mathrm{M}_{81 \mathrm{~B}^{\mathrm{d}}}$ & $\mathrm{M}_{65} \mathrm{~B}^{\mathrm{d}}$ & $\mathrm{M}_{65} \mathrm{~B}^{\mathrm{d}}$ & M65B & M65B & M65B & & & \\
\hline & Vesicular grain & Vesicular grain $\mathrm{A}$ & Vesicular grain B & Vesicle-free grain $\mathrm{C}$ & Vesicle-free grain $\mathrm{D}$ & Vesicle-free grain $\mathrm{E}$ & $1955-58 \mathrm{ash}^{\mathrm{b}}$ & & \\
\hline$n$ & 7 & 11 & 2 & 2 & 5 & 4 & & & \\
\hline $\mathrm{SiO}_{2}$ & $66.1(0.4)$ & $66.1(0.3)$ & $64.7(0.8)$ & $74.5(0.3)$ & $72.2(0.4)$ & $72.6(0.5)$ & -70.4 & & \\
\hline $\mathrm{TiO}_{2}$ & $0.53(0.07)$ & $0.54(0.10)$ & $0.50(0.02)$ & $0.62(0.03)$ & $0.47(0.08)$ & $0.52(0.11)$ & 0.35 & & \\
\hline $\mathrm{Al}_{2} \mathrm{O}_{3}$ & $15.2(0.1)$ & $14.5(0.2)$ & $15.5(0.0)$ & $12.3(0.3)$ & $12.1(0.3)$ & $11.7(0.2)$ & 14.6 & & \\
\hline $\mathrm{MgO}$ & $0.73(0.07)$ & $0.58(0.03)$ & $0.75(0.01)$ & $0.25(0.06)$ & $0.15(0.06)$ & $0.12(0.03)$ & 0.27 & & \\
\hline $\mathrm{CaO}$ & $2.06(0.13)$ & $1.54(0.13)$ & $2.49(0.04)$ & $0.18(0.00)$ & $0.44(0.13)$ & $0.44(0.05)$ & 1.27 & & \\
\hline $\mathrm{MnO}$ & $0.13(0.03)$ & $0.11(0.03)$ & $0.09(0.03)$ & $0.12(0.02)$ & $0.08(0.05)$ & $0.11(0.04)$ & 0.16 & & \\
\hline $\mathrm{FeO}_{\mathrm{T}}$ & $3.61(0.15)$ & $3.48(0.10)$ & $4.10(0.20)$ & $0.96(0.22)$ & $2.13(0.27)$ & $2.50(0.34)$ & 2.11 & & \\
\hline $\mathrm{Na}_{2} \mathrm{O}$ & $3.54(0.52)$ & $3.91(0.24)$ & $3.72(0.23)$ & $2.92(0.04)$ & $3.51(0.23)$ & $3.42(0.12)$ & 4.76 & & \\
\hline $\mathrm{K}_{2} \mathrm{O}$ & $5.08(0.14)$ & $5.90(0.14)$ & $5.69(0.14)$ & $5.87(0.16)$ & $6.23(0.09)$ & $6.30(0.16)$ & 6.03 & & \\
\hline Total & $97.3(0.3)$ & $97.0(0.4)$ & $97.9(0.9)$ & $98.1(0.4)$ & $97.6(0.3)$ & $97.9(0.4)$ & 100.0 & & \\
\hline
\end{tabular}

${ }^{\text {a }}$ Values are average microprobe analyses. The number of significant digits reflects precision of method for analysis of given oxide. $n$, number of analyses in average. Numbers in parentheses are one standard deviation.

b Analyses normalized to $100.0 \%$ for comparison.

${ }^{c}$ Author identifies light and dark bands in pyroclastic material.

${ }^{d}$ M81B vesicular grain corresponds to M81B-1 in Table 4; M65B vesicular grain A corresponds to M65B-1 in Table 4. Other M65B grains, B-E, in this table are not the same as grains reported in Table 4. 


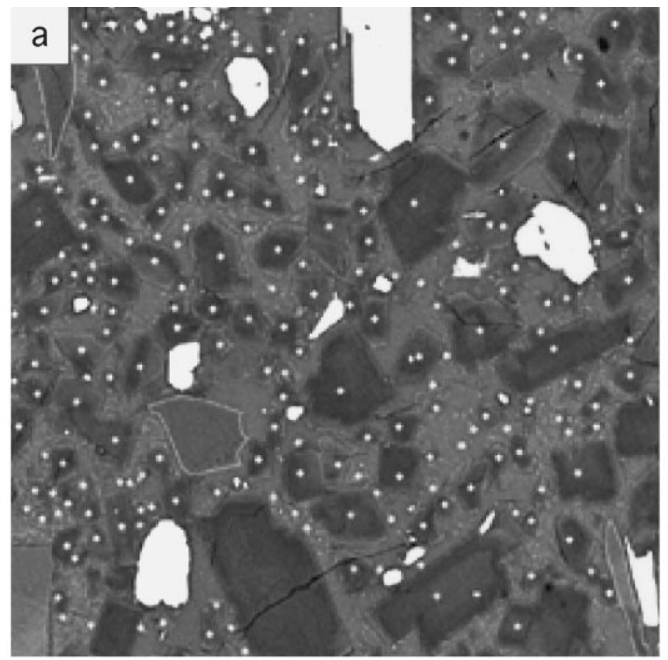

image area $\left(\mu \mathrm{m}^{2}\right)=7453.33$

number of microlites (dots) $=224$

$\mathrm{N}_{\mathrm{A}}\left(\mathrm{mm}^{-2}\right)=30,054$

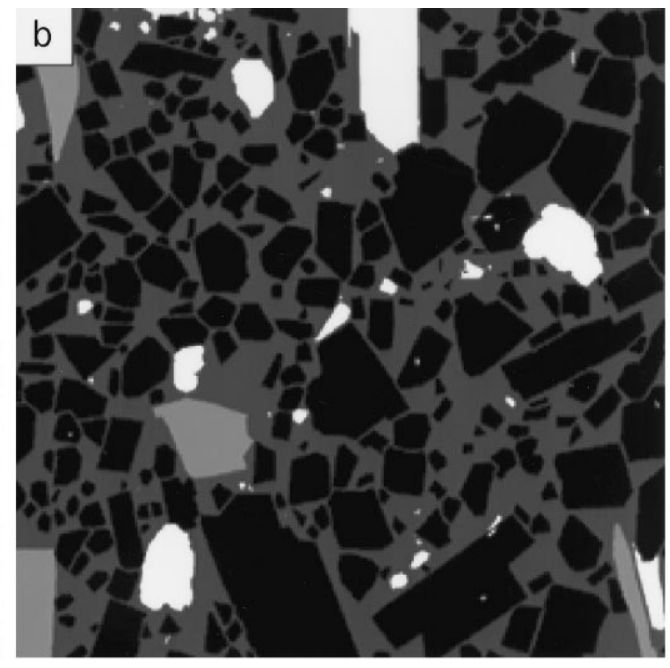

image area $\left(\mathrm{mm}^{2}\right)=7453.33$

white (oxides, \%) $=7.23$

light gray (plagioclase phenocrysts, $\%$ ) $=3.87$ total excluded phases $(\%)=11.10$

dark gray (glass, \%) $=36.87$

black (feldpsar microlites, \%) = 52.03

$$
\begin{array}{r}
R_{A}\left(\mu m^{2}\right)=0.889^{*} 7453=6626 \\
\phi=.520 *(7453 / 6626)=.585
\end{array}
$$

Fig. 2. Several image processing steps are illustrated using the image of Fig. 3d. Dark gray crystals are feldspar microlites. White crystals are mafic minerals, including pyroxenes and oxides. (a) Each microlite is marked with a dot having a gray scale value of 15 (scale from 0-255). Dots may be selected and counted by NIH Image, which also measures the image area according to a pre-set scale. $N_{\mathrm{A}}$ is calculated as the number of microlites per reference area, $A_{\mathrm{R}}$. (b) A map is made by combining separate binary images of each phase (feldspar phenocrysts, oxides, glass, and feldspar microlites). $A_{\mathrm{R}}$ is calculated as the total area multiplied by the area fraction of (glass + microlites). $\phi$ represents the phenocryst-free, oxide-free microlite crystallinity.

crystal size require conversions of $2 \mathrm{D}$ measurements to three dimensions.

Higgins (1994) showed that the longest side of a crystal viewed in thin section (longest chord, $l$ ) is less than the true longest dimension. Furthermore, the modal value of the breadth (shortest chord, $b$ ) to length ratio for all of the crystals in a sample represents the characteristic ratio of the intermediate to shortest dimension (I). This is an exact method when all of the crystals have the same habit. While we observe that neither habit nor size are constant, we assume that crystal habit varies at least as much between samples as within them, and report the results of shape and size analyses as single characteristic values for each sample. Combining shape and size information, expressions for crystal size based on the true length of the shortest (a) and intermediate dimensions (b) may be obtained: $\mathbf{a}=s_{n}$ (modal $b / l)^{1 / 2}, \mathbf{b}=s_{n}(\text { modal } b / l)^{-1 / 2}$.

The skewness of the $b / l$ distribution may be used to estimate the length of the longest axis relative to the shortest axis ( $L$; e.g. Higgins, 1994). When applied to some of the distributions obtained here, this produced negative and/ or unrealistically large values for $L$. Consequently, we considered two alternative methods to calculate the true length. The first is to use the third moment of the population density function, which has been described in detail elsewhere (Marsh, 1988; Cashman, 1992). An expression, modified from Cashman (1992), relates crystal fraction, area number density and a shape factor: $\phi=6 \mathrm{kn}^{\mathrm{o}} \mathrm{s}^{4}$, where $n^{\mathrm{o}}=$ $\left(N_{\mathrm{A}}\right)^{2} / \phi$ and $k=(S / L)(I / L)$, or $I / L^{2}$. Solving for $L$, the 
expression simplifies to: $L=(6 I)^{1 / 2}$. Crystal length (c) can now be computed as: $\mathbf{c}=\mathbf{b}(L / I)$. A second method is to compute length as the inverse of the minimum $b / l$ ratio for all the crystals in the sample. An implicit assumption in this method is that the crystal having the minimum $b / l$ ratio not only was intersected along its true longest axis, but that its shape is representative of all of the crystals in the sample. This method is therefore sensitive to outliers, and is less trustworthy for high aspect ratio shapes and cases where a small number of crystals are considered. Once $c$ has been obtained, characteristic volumes $(V)$ and surface areas (SA) may be computed: $V=$ $\mathbf{a b c} ; \mathrm{SA}=2[\mathbf{a b}+\mathbf{a c}+\mathbf{b c}]$.

\section{Results}

\subsection{Bulk, glass, and feldspar compositions}

With typical $\mathrm{SiO}_{2}$ and alkali $\left(\mathrm{Na}_{2} \mathrm{O}+\mathrm{K}_{2} \mathrm{O}\right)$ contents of 56 and $6 \mathrm{wt} . \%$, respectively, Merapi's eruptive material is classified as high-K basaltic andesite (scheme of Peccerillo and Taylor, 1976). Bulk compositions obtained for the 1992-1993 and 1994-95 domes are typically $57 \% \mathrm{SiO}_{2}, 16 \% \mathrm{Al}_{2} \mathrm{O}_{3}$, $4 \% \mathrm{MgO}, 8 \% \mathrm{CaO}, 0.3 \% \mathrm{MnO}, 7 \% \mathrm{FeO}, 4 \% \mathrm{Na}_{2} \mathrm{O}$, and $2.4 \% \mathrm{~K}_{2} \mathrm{O}$, and are similar to other recent dome lavas (Bardintzeff, 1984; del Marmol, 1989; Berthommier, 1990; Boudon et al., 1993).

Glass analyses from this study and data from others (Bardintzeff, 1984; Berthommier, 1990) are presented in Table 2. Glass compositions obtained for the 1995 dome are indistinguishable within the standard deviations of individual samples, and are within the ranges reported in other studies (Bardintzeff, 1984; Berthommier, 1990). Most of the tephra from the 1994 dome collapse has glass compositions similar to the dome values $\left(\sim 75\right.$ wt. $\left.\% \mathrm{SiO}_{2}\right)$. However, several vesicular grains in the airfall deposit have less evolved glasses ( $\sim 65$ wt. $\% \mathrm{SiO}_{2}$; samples M81B and M65B grains 1 and 2, Table 2).

\subsection{Feldspar compositions}

Feldspar microlite compositions are presented in Table 3. Light and dark portions of microlites, visible in the BSE images of Figs. 3-5, are compositionally different. Dark areas, which appear at the cores of most microlites, correspond to plagioclase feldspar which ranges continuously from $\mathrm{An}_{35}$ to $\mathrm{An}_{48}$. Light areas, generally at the rim of microlites, indicate ternary to alkali feldspar compositions, typically $\mathrm{Ab}_{53} \mathrm{An}_{5} \mathrm{Or}_{42}$. When a light rim is present, it may be gradational, as in Fig. 3d and f, or boxy cellular as in Fig. 5a. This zonation from plagioclase cores to anorthoclase rims is an example of rapakivi texture (Abbot, 1978). Outermost phenocryst rims are similar in composition to the microlite rims, indicating that rim growth on existing crystals was synchronous with microlite crystallization. Compositions $\sim 10 \mu \mathrm{m}$ in from the edge of these phenocryst rims ("phenocryst interior rims" in Table 3) are slightly more primitive than microlite cores, and may represent the equilibrium feldspar composition at the onset of microlite crystallization. Core and rim compositions of the 1986-88, 1992-93, and 1994 domes are similar to those of the 1995 dome. In fact, two 1994 samples contain microlites that span the entire compositional range shown by the 1995 dome.

Microlite core compositions appear to vary with the size of the crystal. Figs. 5 and 6 show that cores of small crystals may be either plagioclase or alkali feldspar, and exhibit a range in $\mathrm{An}$ content from $\mathrm{An}_{5}$ to $\mathrm{An}_{35}$. In contrast, the larger microlites are plagioclase of $\mathrm{An}_{25}-\mathrm{An}_{40}$. Microlite rim compositions are relatively homogeneous alkali feldspar, clustering at $\mathrm{An}_{5}$ regardless of size. Microlite \#3 in Fig. 4a and analyses of small crystals (e.g. m94H, Table 3) demonstrate that small microlites may lack a plagioclase core altogether, and consist entirely of alkali feldspar. Among the microlites with plagioclase cores, the An contents of cores of larger crystals are higher than those of smaller microlites (e.g. \#4 and \#1, Figs. 5a and 6).

The compositional range of feldspar microlites observed in the dome samples is also represented in pyroclastic material from the 1994 collapse (Fig. 7). However, several grains of airfall material contain microlites that are homogeneous rather than bimodal in composition. These crystals are wholly plagioclase, and lack the alkali feldspar rims ubiquitous to all of the other samples (Fig. 5b). These clasts, which include the vesicular tephra, are the grains distinguished by relatively low silica content glasses (66 compared with $75 \mathrm{wt} . \% \quad \mathrm{SiO}_{2}$ ) and low microlite crystallinities $(\phi=0.30)$. 
Table 3

Merapi feldspar compositions

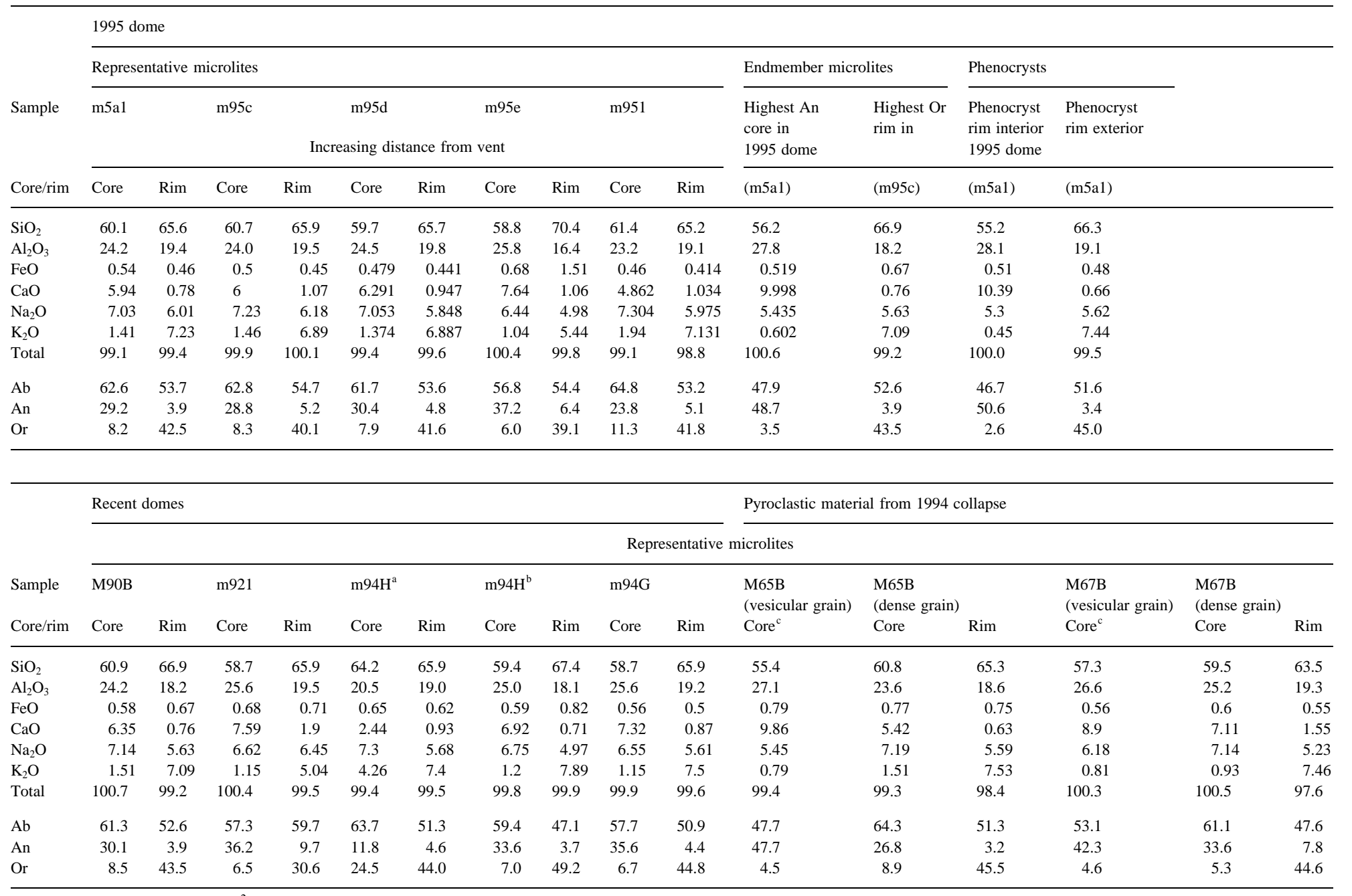

${ }^{a}$ Small microlite; $\sim 100 \mu \mathrm{m}^{2}$.

${ }^{\mathrm{b}}$ Larger microlite; $\sim 400 \mu \mathrm{m}^{2}$.

${ }^{c}$ Microlites in vesicular grains are homogeneous in composition and do not have rims. 

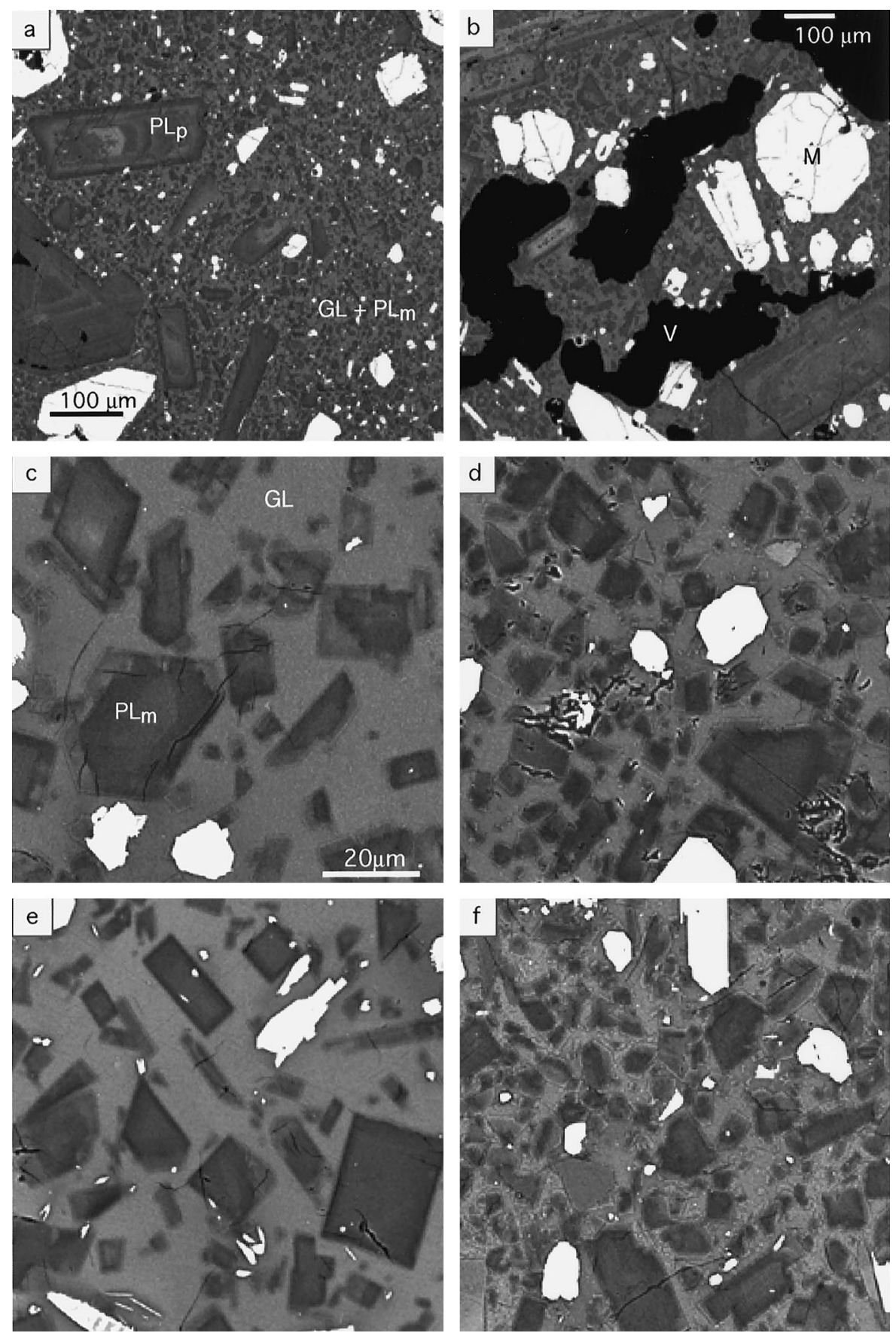

Fig. 3. (a,b) Low magnification BSE images of dome lavas. Plagioclase phenocrysts (Plp) are large and exhibit complex zonation. Feldspar microlites are ubiquitous in the groundmass. White crystals are mafic minerals, including pyroxenes and oxides. Vesicles in b are hundreds of microns in length, highly irregular in shape, and inhomogeneously distributed through samples. Representative end member textures of the: (c, d) 1995; and (e, f) 1994 domes demonstrate the range in observed microlite textures. Samples m5a1 and m94G (c and e, respectively) show relatively large, sparsely populated (low $N_{\mathrm{A}}$ ) microlites, while m95f and $\mathrm{m} 94 \mathrm{H}$ (b and d) have a dense concentration (high $N_{\mathrm{A}}$ ) of microlites. In the spatially well-constrained 1995 flow, c and d represent near-vent and distal material, respectively. 

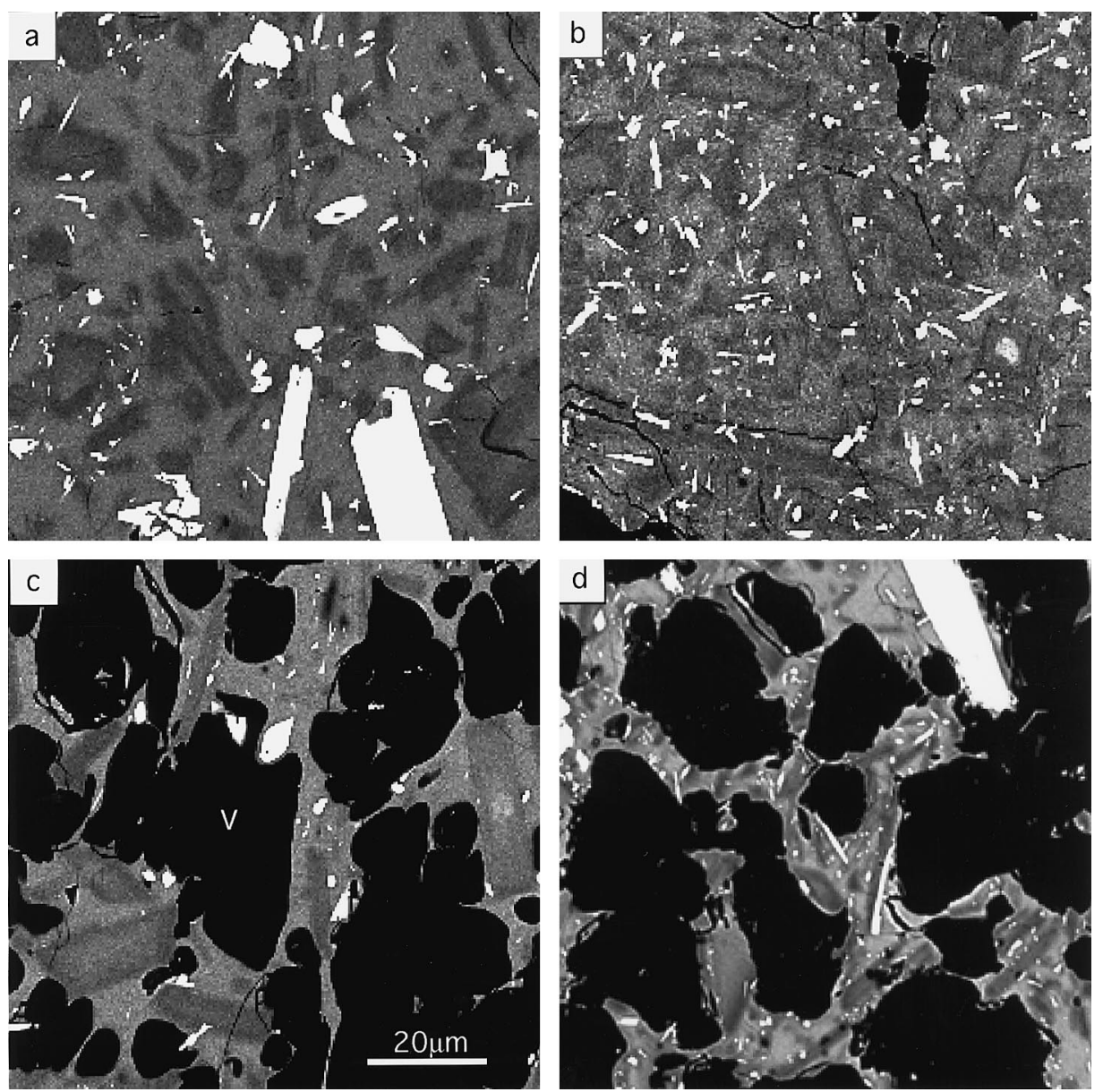

Fig. 4. BSE images of pyroclastic material including airfall and surge grains. In addition to dome-like textures like that of: (a) M81B-2; (b) 1994 collapse material includes devitrified; and (c,d) vesicular material. High crystallinity and incipient devitrification in M65A (b) suggest that part of the dome was hot but sub-solidus. Primary vesicles and rimless microlites in M81B-1* and M61B* (c,d) indicate that collapse material included a component of liquid lava.

\subsection{Textural trends}

Visual inspection of the variety of textures observed in the dome samples (Fig. 3) allows a qualitative assessment of the degree of heterogeneity present in the dome samples. Image pairs in Fig. $3 \mathrm{c}-\mathrm{e}$ represent the end members in microlite number density observed in the 1995 and 1994 flows, respectively. Fig. $3 \mathrm{c}$ shows a sample from a vent-proximal location (m5a1), while Fig. 3d is $27 \mathrm{~m}$ further from down flow (m95f). Fig. 3e and $\mathrm{f}$ are representative textures in 1994 dome samples $\mathrm{m} 94 \mathrm{G}$ and $\mathrm{m} 94 \mathrm{H}$, respectively. Microlites characterized by low number density (Fig. 3c and e), are clearly larger on average than their high number density counterparts (Fig. 3d and f), thus yielding similar overall microlite crystallinities. Images in Fig. 4a-d represent textures present in the pyroclastic material from the 1994 collapse. The airfall grain in Fig. 4a (M81B-2) is similar in microlite content and number density to dome samples (see Table 4). The completely crystalline, devitrified grain in Fig. 4b (from M65A; not analyzed) probably represents material from the dome interior. The airfall grains in Fig. $4 \mathrm{c}$ and $\mathrm{d}\left(\mathrm{M} 81 \mathrm{~B}-1^{*}\right.$ and M61B*, Table 4) are more than $50 \%$ vesicles. These textures are similar to those of pumice clasts produced 

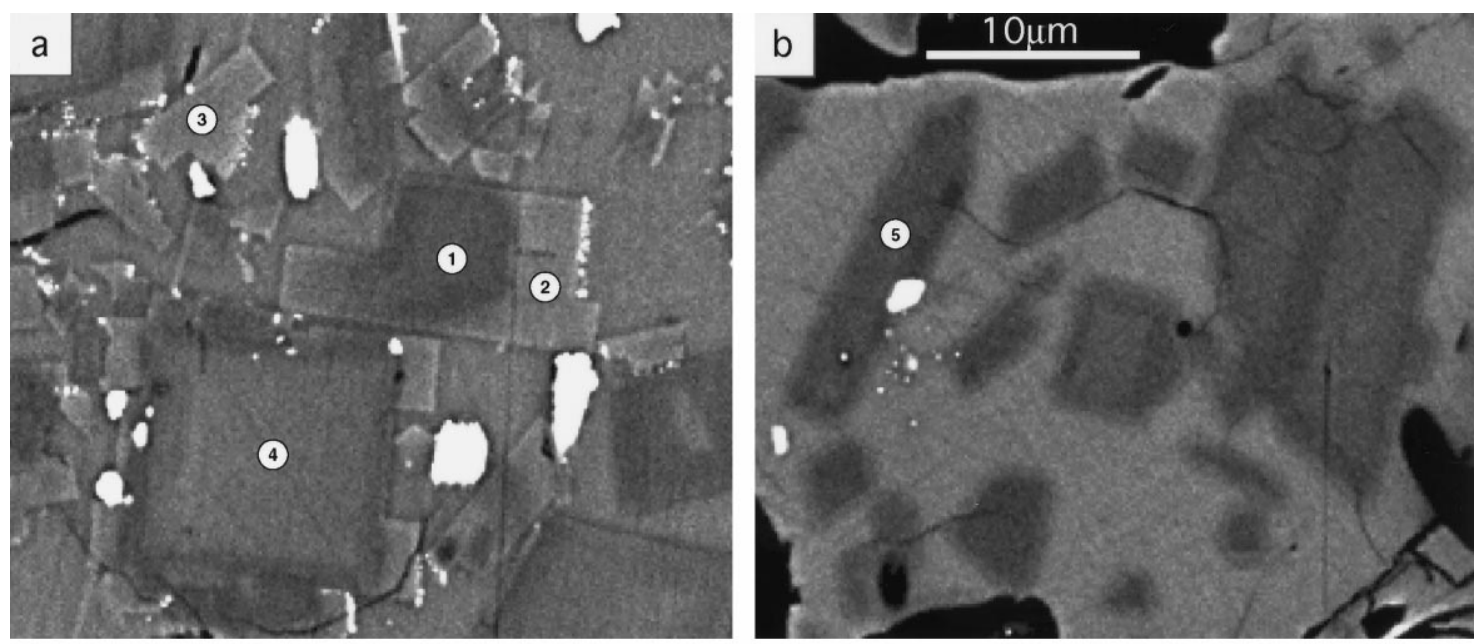
(1) $\mathrm{Ab}_{64} \mathrm{An}_{27} \mathrm{Or}_{9}$
(2) $\mathrm{Ab}_{51} \mathrm{An}_{3} \mathrm{Or}_{46}$
(3) $\mathrm{Ab}_{54} \mathrm{An}_{6} \mathrm{Or}_{46}$
(4) $\mathrm{Ab}_{60} \mathrm{An}_{31} \mathrm{Or}_{9}$

(5) $\mathrm{Ab}_{48} \mathrm{An}_{48} \mathrm{Or}_{4}$

Fig. 5. Microlites and representative compositions for: (a) typical dome samples; and (b) vesicular airfall tephra from the 1994 collapse. Light and dark areas of microlites correspond to alkali and plagioclase feldspar compositions, respectively. Cores tend to be plagioclase (\# 1), while rims are alkali feldspar (\#2). However, composition is related to size, so that small crystals are wholly alkali feldspar (\#3), and the anorthite content of plagioclase cores increases with microlite size (compare \#s 1 and 4). Rimless microlites (b) are homogeneous plagioclase (\#5).

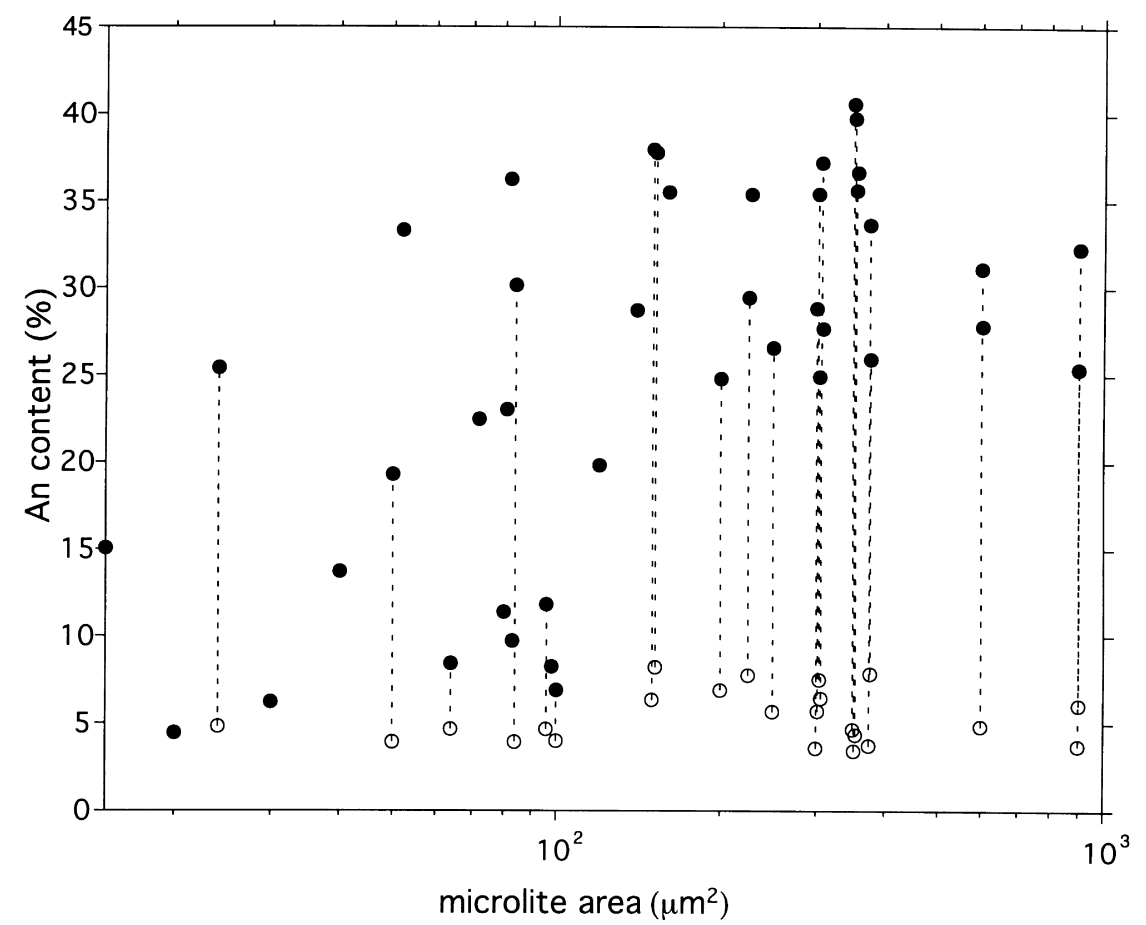

Fig. 6. Anorthite content of microlite cores (filled circles) and rims (open circles) as a function of crystal size. Microlites less than $100 \mathrm{~mm}^{2}$ display a wide range in core composition, from alkali to plagioclase feldspar, while larger crystals have exclusively plagioclase cores. Rim compositions are fairly homogeneous regardless of microlite size. 

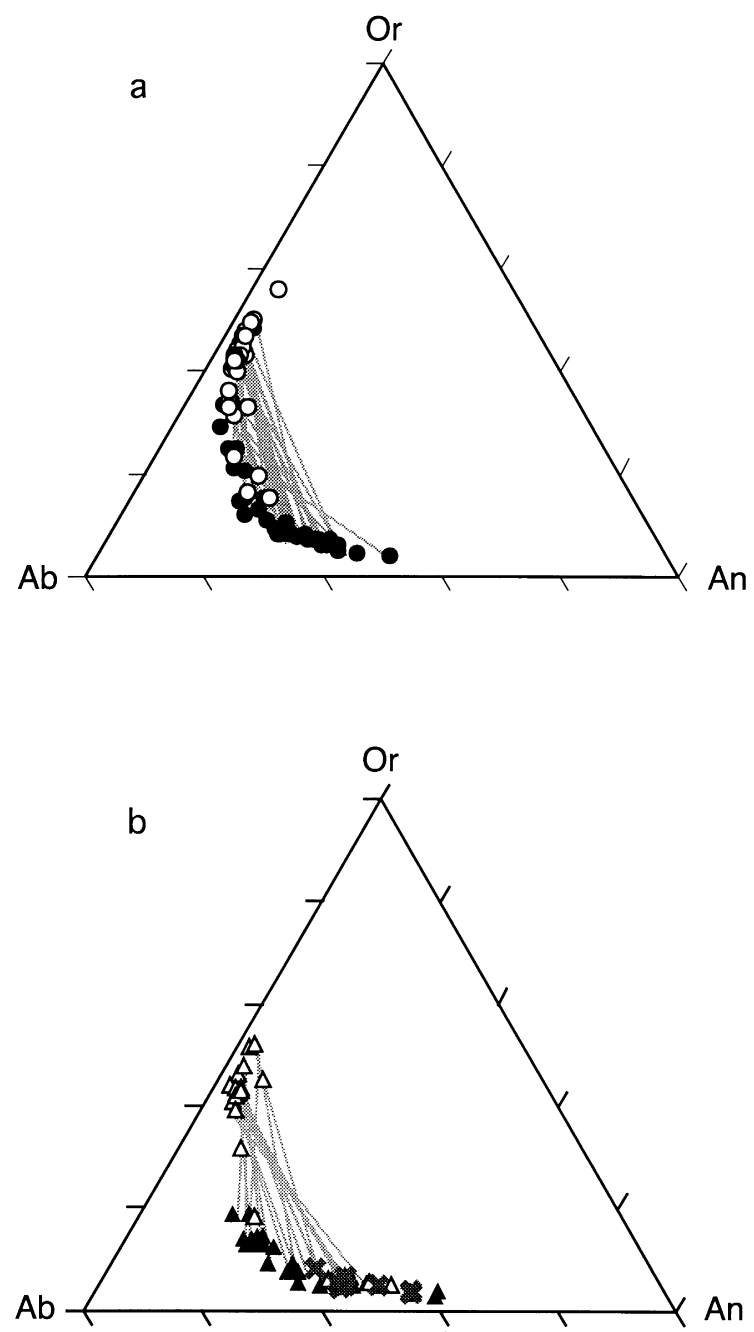

Fig. 7. Core (filled circles) and rim (open circles) compositions from (a) microlites in domes; and (b) pyroclastic material from the 1994 collapse. Tie lines indicate pairs from the same crystal. Microlites in pyroclastic material encompass the same compositional range as dome samples, except for the presence of rimless microlites (xs) found only in some pyroclastic material.

by explosive eruptions (Heiken and Wohletz, 1987; Klug and Cashman, 1994; Gardner et al., in press). Homogeneous spatial distribution of vesicles, together with preservation of thin melt films, suggests that these vesicles are primary exsolution features. Vesicular material represents a small component of this deposit $(<0.1 \%$ by mass), but its presence indicates that at least some of the magma incorporated into the collapse was molten. In contrast, vesicles in dome lava (Fig 3b) are large (100s of $\mu \mathrm{m}$ ), irregularly shaped, and heterogenously distributed.

Textural data, including the fraction of groundmass crystallized as feldspar microlites $(\phi)$, their number density $\left(N_{\mathrm{A}}\right)$, and average linear size $\left(s_{n}\right)$, are presented in Table 4. In 1995 dome rocks $\phi$ is essentially constant $(\sim 0.41)$ within the standard deviation of individual images. Samples from the 1994 dome span the largest observed range in $\phi$ of any single dome with a maximum variation of a factor of two (0.33-0.66). Samples from the 1992-93 dome range from 0.42 to 0.62 , and the two 1986-88 dome samples have crystallinities of 0.43 and 0.48 . None of the dome rocks had groundmass crystal volume fractions of less than 0.30 or more than 0.70 . In contrast, $N_{\mathrm{A}}$ varies by more than a factor of eight, from $\sim 4000$ to more than $35000 \mathrm{~mm}^{-2}$, among the dome samples. Feldspar number densities in the 1995 dome alone span about half of this range, with $N_{\mathrm{A}}$ ranging from less than 7000 to more than 28000 , and generally increasing with distance from the vent. 1994 samples are apparently bimodal, clustering at $\sim 10000$ and 34000 , while the 1992-93 samples vary by less than a factor of two, from $\sim 17000$ to 26000 . The 1986-88 lava samples fall at the low end of the spectrum, at $\sim 4000$ and $\sim 8000$. Both $\phi$ and $N_{\mathrm{A}}$ are used in the calculation of $s_{n}$, a parameter which consequently integrates effects of crystal nucleation and growth. Since, $s_{n}$ is by definition proportional to $\left(N_{\mathrm{A}}\right)^{-0.5}$, the range in $s_{n}(4-11 \mu \mathrm{m}$ among all of the dome samples) corresponds to the range in $N_{\mathrm{A}}$. For example, the smallest crystals were identified in the distal part of the 1995 dome which has a high $N_{\mathrm{A}}$. The largest crystals exist in the proximal 1995 dome and the 1986-88 dome, where $N_{\mathrm{A}}$ values are relatively low.

Several samples from each dome were selected for detailed microlite size and shape analysis (Table 5). Volume frequency distributions (Fig. 8) show the contribution of each linear size class to the total volume of crystals. Calculations for these plots employ the second method for computing $L\{L=$ $1 /($ minimum $b / l$ value $)\}$. Distributions fall along a spectrum defined by two end members: (1) a polymodal distribution in which large and small crystals contribute evenly to the total volume; and (2) unimodal distribution in which small crystals dominate. 
Table 4

Textural data I

\begin{tabular}{|c|c|c|c|c|c|c|c|}
\hline & $\begin{array}{l}\text { Sample } \\
\text { Domes }\end{array}$ & $\mathrm{A}_{\mathrm{RNA}}\left(\mu \mathrm{m}^{2}\right)$ & $\mathrm{A}_{\mathrm{R} \phi}\left(\mu \mathrm{m}^{2}\right)$ & $n^{\mathrm{a}}$ & $\phi^{\mathrm{b}}$ & $N_{\mathrm{A}}\left(\mathrm{mm}^{-2}\right)^{\mathrm{b}}$ & $s_{n}(\mu \mathrm{m})^{\mathrm{c}}$ \\
\hline \multirow[t]{2}{*}{$1986-87$} & M90B & 134022 & 75828 & 569 & $0.43(0.03)$ & 4246 (724) & 10.5 \\
\hline & M90E & 38314 & 38314 & 324 & $0.48(0.03)$ & $8457(1611)$ & $7.5(0.9)$ \\
\hline \multirow[t]{7}{*}{$1992-93$} & m92t & 17675 & 9628 & 452 & $0.54(0.05)$ & $25573(4720)$ & $5.0(0.5)$ \\
\hline & m92i & 19679 & 9943 & 424 & $0.53(0.05)$ & $21546(2010)$ & $4.7(0.5)$ \\
\hline & $\mathrm{m} 2 \mathrm{cA}$ & 18802 & 9701 & 449 & $0.62(0.06)$ & $23880(1562)$ & $5.3(0.5)$ \\
\hline & $\mathrm{m} 2 \mathrm{cC}$ & 28577 & 9441 & 743 & $0.58) 0.06)$ & $26000(4453)$ & $4.3(0.4)$ \\
\hline & M92A & 18398 & 18398 & 404 & $0.42(0.04)$ & 21959 (1258) & $4.4(0.1)$ \\
\hline & M934 & 17864 & 17864 & 636 & $0.44(0.04)$ & 23231 (1879) & $4.1(0.4)$ \\
\hline & M31A & 9416 & 9416 & 161 & $0.43(0.04)$ & $17099(1710)$ & $5.0(0.5)$ \\
\hline \multirow[t]{4}{*}{1994} & M00X & 17836 & 17836 & 372 & $0.33(0.02)$ & 11830 (298) & $5.3(0.1)$ \\
\hline & $\mathrm{m} 94 \mathrm{G}$ & 39091 & 19718 & 418 & $0.43(0.02)$ & 10693 (1037) & $6.3(0.1)$ \\
\hline & m94P & 11727 & 9226 & 1106 & $0.66(0.07)$ & 32319 (6202) & $4.7(0.0)$ \\
\hline & $\mathrm{m} 94 \mathrm{H}$ & 9535 & 9535 & 341 & $0.56(0.06)$ & $35763(3576)$ & $4.0(0.4)$ \\
\hline \multirow[t]{9}{*}{1995} & m951 & 26923 & 26923 & 769 & $0.40(0.01)$ & $28563(848)$ & $3.8(0.1)$ \\
\hline & m95e & 46983 & 34713 & 955 & $0.42(0.04)$ & $20326(1820)$ & $5.0(0.4)$ \\
\hline & m95f & 36791 & 37245 & 905 & $0.41(0.04)$ & $24598(2108)$ & $4.8(0.4)$ \\
\hline & $\mathrm{m} 95 \mathrm{~g}$ & $45 \quad 872$ & 33559 & 1001 & $0.40(0.04)$ & $21822(2265)$ & $5.1(0.4)$ \\
\hline & $\mathrm{m} 95 \mathrm{~d}$ & 36936 & 18603 & 435 & $0.39(0.04)$ & $11777(2251)$ & $5.8(0.7)$ \\
\hline & $\mathrm{m} 95 \mathrm{c}$ & 19264 & 9765 & 221 & $0.39(0.01)$ & $11472(3)$ & $6.4(0.0)$ \\
\hline & m5a1 & 50789 & 20446 & 429 & $0.39(0.04)$ & 8446 (939) & $7.3(0.2)$ \\
\hline & $\mathrm{m} 5 \mathrm{a} 2$ & 4831 & 10015 & 72 & $0.44(0.04)$ & $6305(914)$ & $7.8(0.8)$ \\
\hline & \multicolumn{7}{|c|}{1994 dome collapse material } \\
\hline \multirow{5}{*}{ Pyroclastic flow } & $121 \mathrm{C}$ & 40083 & 20031 & 323 & $0.33(0.02)$ & 8058 (578) & $6.6(0.3)$ \\
\hline & M122-1 & 9643 & 9643 & 97 & $0.51(-)$ & $10059(-)$ & $7.1(-)$ \\
\hline & M122-2 & 9211 & 9211 & 133 & $0.40(-)$ & $14439(-)$ & $5.13(-)$ \\
\hline & M122-3 & 9228 & 9228 & 224 & $0.78(-)$ & $24275(-)$ & $5.7(-)$ \\
\hline & M122-4 & 9452 & 9452 & 158 & $0.41(-)$ & $16716(-)$ & $5.0(-)$ \\
\hline \multirow[t]{10}{*}{ Surge } & M61A-1 & 19826 & 19826 & 277 & $0.34(-)$ & $13972(-)$ & $4.9(-)$ \\
\hline & M61A-2 & 15240 & 15240 & 1054 & $0.57(-)$ & $32808(-)$ & $4.2(-)$ \\
\hline & M65A-1 & 8843 & 8843 & 213 & $0.65(-)$ & $24088(-)$ & $5.2(-)$ \\
\hline & M65A-2 & 7186 & 7186 & 118 & $0.33(-)$ & $16420(-)$ & $4.5(-)$ \\
\hline & M65A-3 & 8482 & 8482 & 152 & $0.54(-)$ & $17920(-)$ & $5.5(-)$ \\
\hline & M65A-4 & 9210 & 9210 & 103 & $0.40(-)$ & $11184(-)$ & $6.0(-)$ \\
\hline & M65A-5 & 8340 & 8340 & 108 & $0.36(-)$ & $12950(-)$ & $5.2(-)$ \\
\hline & M65A-6 & 9629 & 9629 & 152 & $0.55(-)$ & $15786(-)$ & $5.9(-)$ \\
\hline & M65A-7 & 6867 & 6867 & 97 & $0.45(-)$ & $14125(-)$ & $5.6(-)$ \\
\hline & M65A-8 & 8741 & 8741 & 112 & $0.34(-)$ & $12813(-)$ & $5.1(-)$ \\
\hline \multirow[t]{16}{*}{ Airfall } & $\mathrm{M}_{61 \mathrm{~B}^{\mathrm{d}}}$ & 3783 & 3783 & 71 & $0.25(-)$ & $18768(-)$ & $3.6(-)$ \\
\hline & M65B- ${ }^{\mathrm{d}}$ & 5406 & 5406 & 63 & $0.34(-)$ & $11653(-)$ & $5.4(-)$ \\
\hline & M65B-2 & 7362 & 7362 & 152 & $0.47(-)$ & $20648(-)$ & $4.8(-)$ \\
\hline & M65B-3 & 8287 & 8287 & 169 & $0.36(-)$ & $20392(-)$ & $4.2(-)$ \\
\hline & M65B-4 & 8598 & 8598 & 169 & $0.39(-)$ & $19656(-)$ & $4.4(-)$ \\
\hline & M65B-5 & 9285 & 9285 & 124 & $0.33(-)$ & $13355(-)$ & $5.0(-)$ \\
\hline & M65B-6 & 7296 & 7296 & 69 & $0.26(-)$ & $9457(-)$ & $5.3(-)$ \\
\hline & M67B-1 & 9146 & 9146 & 144 & $0.41(-)$ & $15745(-)$ & $5.1(-)$ \\
\hline & M67B-2 & 9313 & 9313 & 92 & $0.41(-)$ & $9878(-)$ & $6.4(-)$ \\
\hline & M67B-3 & 9531 & 9531 & 83 & $0.45(-)$ & $8708(-)$ & $7.2(-)$ \\
\hline & M67B-4 & 9159 & 9159 & 80 & $0.37(-)$ & $8735(-)$ & $6.5(-)$ \\
\hline & M81B- ${ }^{\mathrm{d}}$ & 9123 & 9123 & 137 & $0.33(-)$ & $15017(-)$ & $4.6(-)$ \\
\hline & M81B-2 & 18847 & 18847 & 282 & $0.38(-)$ & $14963(-)$ & $5.0(-)$ \\
\hline & M81B-3 & 7960 & 7960 & 225 & $0.44(-)$ & $28266(-)$ & $4.0(-)$ \\
\hline & M81B-4 & 9660 & 9660 & 91 & $0.46(-)$ & $9420(-)$ & $7.0(-)$ \\
\hline & M81B-5 & 8240 & 8240 & 186 & $0.49(-)$ & $22574(-)$ & $7.2(-)$ \\
\hline
\end{tabular}

Abbreviations are defined in the Appendix. Values are weighted averages of image data. Numbers in parentheses is either one standard deviation or $10 \%$ of value (in cases where only one image is used). Separate reference areas $\left(A_{R} \mathrm{~S}\right)$ are indicated in cases where different images are used to measure $N_{\mathrm{A}}$ and $\phi$. Pyroclastic grains are typically too small to capture more than one (1000X) image of groundmass. Standard deviations of $N_{\mathrm{A}}, \phi$ and $s_{n}$ are not listed, but probably are roughly $\pm 10 \%$ for these grains.

${ }^{a}$ Number of microlites counted.

${ }^{b}$ Image data are weighted by reference area to compute mean values of $N_{\mathrm{A}}$ and $\phi$.

${ }^{c}$ Image data are weighted by the number of microlites counted to compute mean value of $s_{n}$.

${ }^{\mathrm{d}}$ Vesicular sample. 
Table 5

Textural data II

\begin{tabular}{|c|c|c|c|c|c|c|c|c|c|c|c|c|c|}
\hline & Sample & $\begin{array}{l}\text { Number of } \\
\text { microlites } \\
\text { measured }\end{array}$ & $I$ & $L_{1}{ }^{\mathrm{a}}$ & $L_{2}^{\mathrm{b}}$ & $\begin{array}{l}\mathbf{a} \\
(\mu \mathrm{m})\end{array}$ & $\begin{array}{l}\mathbf{b} \\
(\mu \mathrm{m})\end{array}$ & $\begin{array}{l}\mathbf{c}_{1} \\
(\mu \mathrm{m})\end{array}$ & $\begin{array}{l}\mathbf{c}_{2} \\
(\mu \mathrm{m})\end{array}$ & $\begin{array}{l}S_{\mathrm{v} 1} \\
(\mu \mathrm{m})\end{array}$ & $\begin{array}{l}S_{\mathrm{v} 2} \\
(\mu \mathrm{m})\end{array}$ & $\begin{array}{l}\mathrm{SA} / \mathrm{V}_{1} \\
\left(\mu \mathrm{m}^{-1}\right)\end{array}$ & $\begin{array}{l}\mathrm{SA} / \mathrm{V}_{2} \\
\left(\mu \mathrm{m}^{-1}\right)\end{array}$ \\
\hline $1986-88$ & M90B & 284 & 1.5 & 3.0 & 5.0 & 8.3 & 12.2 & 24.7 & 41.4 & 37 & 63 & 0.49 & 0.5 \\
\hline \multirow[t]{5}{*}{$1992-93$} & $\mathrm{~m} 92 \mathrm{t}$ & 194 & 1.4 & 2.8 & 3.4 & 4.0 & 5.3 & 11.3 & 13.6 & 16 & 20 & 1.06 & 1.03 \\
\hline & $\mathrm{m} 92 \mathrm{i}$ & 226 & 1.6 & 3.1 & 3.0 & 4.0 & 6.2 & 12.1 & 11.8 & 21 & 20 & 1.00 & 1.00 \\
\hline & $\mathrm{m} 2 \mathrm{cA}$ & 200 & 1.3 & 2.8 & 3.6 & 4.7 & 6.0 & 12.9 & 16.9 & 22 & 29 & 0.92 & 0.88 \\
\hline & $\mathrm{m} 2 \mathrm{cC}$ & 286 & 1.3 & 2.8 & 3.3 & 4.1 & 5.4 & 11.6 & 13.8 & 17 & 20 & 1.02 & 1.00 \\
\hline & m934 & 225 & 1.4 & 2.9 & 4.0 & 3.6 & 5.2 & 10.6 & 14.5 & 17 & 25 & 1.13 & 1.08 \\
\hline 1994-95 & M94G & 195 & 2.0 & 3.5 & 6.9 & 4.5 & 8.9 & 15.5 & 30.9 & 30 & 61 & 0.80 & 0.74 \\
\hline Pre-collapse & M94H & 331 & 1.3 & 2.8 & 3.7 & 3.4 & 4.4 & 9.4 & 12.4 & 15 & 20 & 1.26 & 1.21 \\
\hline 1994-95 & m95a1 & 161 & 1.8 & 3.3 & 3.0 & 5.5 & 9.9 & 18.1 & 16.5 & 40 & 33 & 0.68 & 0.69 \\
\hline \multirow{5}{*}{$\begin{array}{l}\text { Post- } \\
\text { collapse }\end{array}$} & $\mathrm{m} 95 \mathrm{c}$ & 98 & 1.5 & 3.0 & 3.8 & 5.2 & 7.7 & 15.6 & 20.1 & 26 & 32 & 0.77 & 0.74 \\
\hline & $\mathrm{m} 95 \mathrm{~d}$ & 234 & 1.5 & 3.0 & 3.8 & 5.1 & 7.5 & 15.1 & 19.2 & 24 & 30 & 0.79 & 0.76 \\
\hline & $\mathrm{m} 95 \mathrm{~g}$ & 353 & 1.3 & 2.8 & 3.2 & 4.5 & 5.9 & 12.5 & 14.5 & 18 & 21 & 0.95 & 0.93 \\
\hline & $\mathrm{m} 95 \mathrm{f}$ & 391 & 1.4 & 2.8 & 3.1 & 4.1 & 5.5 & 11.6 & 12.6 & 23 & 24 & 1.03 & 1.01 \\
\hline & $\mathrm{m} 95 \mathrm{e}$ & 467 & 1.4 & 2.9 & 3.7 & 4.3 & 6.0 & 12.4 & 16.1 & 24 & 31 & 0.96 & 0.92 \\
\hline
\end{tabular}

Abbreviations are defined in the Appendix.

${ }^{a} \mathrm{~L}$, the ratio of longest to shortest microlite dimension (c/a) calculated by two methods as discussed in text. $\mathrm{L}_{1}$ calculated as $(6 I)^{1 / 2}$.

${ }^{\text {b }} \mathrm{L}_{2}$ calculated as the inverse of the minimum modal $b / l$ value. Subscripts on c, $s_{\mathrm{v}}$, and SA/ $V$ indicate which $L$ is used to compute them. See Appendix A for symbol definitions.

Fig. 8 shows the extremes observed among all of the samples investigated (Fig. 8a and b), and the end member samples from the 1995 dome (Fig. 8c and d). These distributions, as extensions of the general textural characterizations outlined above, are consistent with overall $N_{\mathrm{A}}$ and $s_{n}$ results reported in Table 4. For example, Fig. 8a, from the 1986-88 dome, shows the first type of end member distribution and was previously characterized by low $N_{\mathrm{A}}$ and large $s_{n}$. Fig. 8b, from the 1994 dome, is an example of the second type of distribution and has a particularly high $N_{\mathrm{A}}$ and small $s_{\mathrm{n}}$. 1995 dome samples fall between these extremes, but show variations in both the volume fraction of crystals in the small size classes and the range of crystal sizes present. A cumulative distribution plot of these data (Fig. 8e) shows graphically how the volume based median sizes were obtained, and provides direct comparison of size distributions between these samples. Median sizes computed using the first method for calculating $L\left\{L=(6 I)^{1 / 2}\right\}$ are also listed in Table 5. Characteristic $L$ ratios for these samples indicate that most of these samples contain blocky, prismatic crystals. Despite the range in $N_{\mathrm{A}}$ and $s_{n}$, the microlite shapes are similar $(S=1, M \sim 1.5, L \sim 3)$ in all of the domes (Table 5). In general, the average aspect ratio increases with $s_{\mathrm{v}}$. For example the microlites of M94G are larger $\left(s_{\mathrm{v}}=30 \mu \mathrm{m}\right)$ and relatively elongate in shape $(L=3.5)$, while those of $\mathrm{M} 94 \mathrm{H}$ are small $\left(\left(s_{\mathrm{v}}=15 \mu \mathrm{m}\right)\right.$ and more blocky $(L=2.8)$. A convenient combination of shape and size information used to characterize samples is the ratio of surface area to volume $(\mathrm{SA} / V)$. High values of $\mathrm{SA} / V$ correspond to samples having the smallest microlites, while samples with larger microlites are characterized by lower SA/ $V$ values (e.g. m934 and M90B).

Plots of $N_{\mathrm{A}}$ vs. $\phi$ for dome and pyroclastic samples (Fig. 9) provide graphical comparison of mean sample textures outlined in the preceding paragraphs. Values of $N_{\mathrm{A}}$ in the 1986-88 dome are among the lowest observed, while the 1992-93 dome which succeeded it displays slightly higher $\phi$ and significantly higher $N_{\mathrm{A}}$ values. The 1994 dome samples are bimodal in both $N_{\mathrm{A}}$ and $\phi$, spanning the largest range in these attributes of any dome material. In contrast, the 1995 dome samples display relatively constant $\phi$ with a large range in $N_{\mathrm{A}}$ which, based on sample locations in the flow, progressively decreased during 

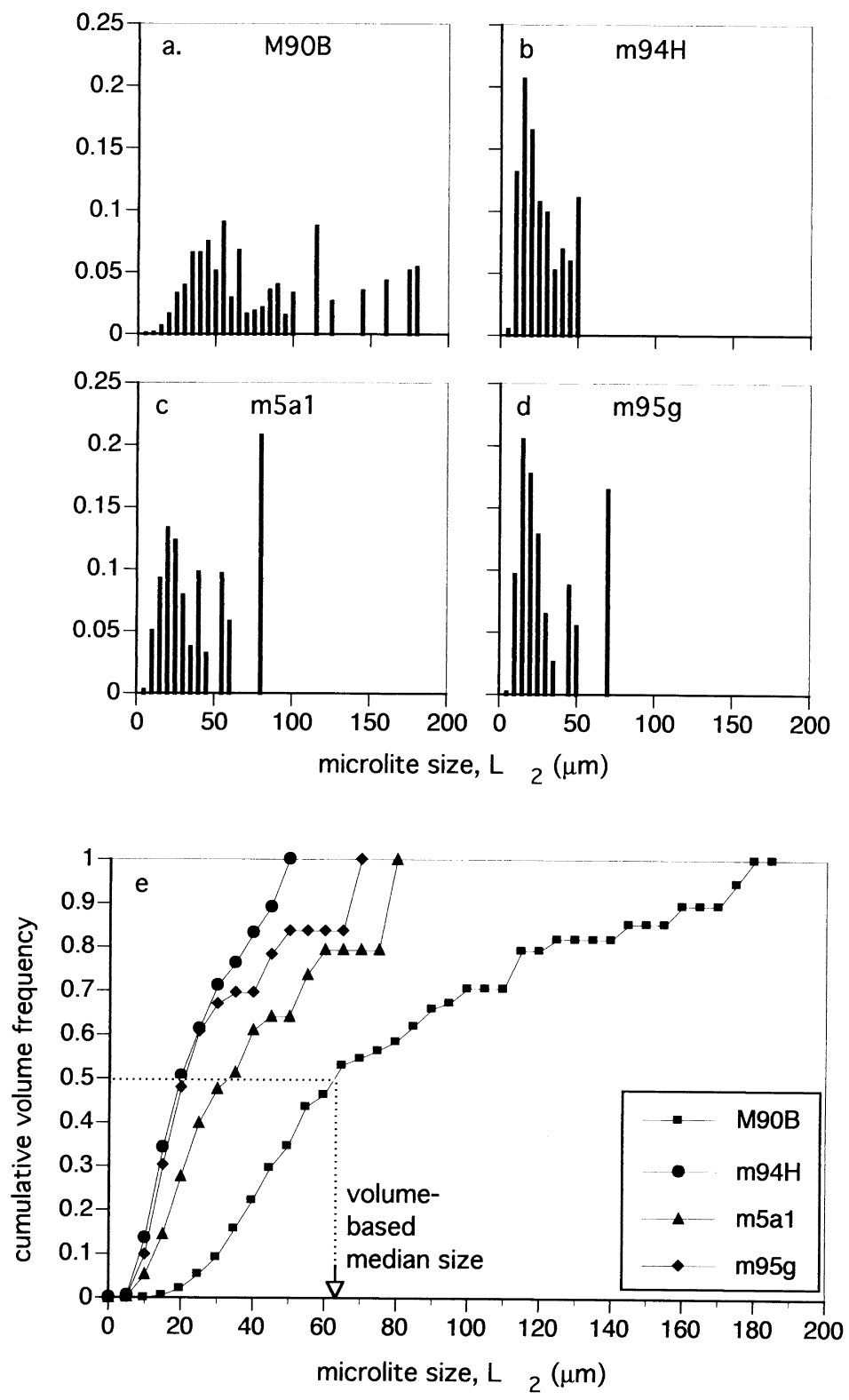

Fig. 8. (a-d) Volume frequency and cumulative volume frequency; and (e) plots from end member textures show the relative contribution of microlite sizes to overall volume. Sizes are lengths, computed by multiplying each measurement of microlite breadth, $b$, by L, computed as $\left[\right.$ minimum $(b / l)^{-1}$ ]. See Appendix A for symbol definitions. The distribution of microlites: (a) in sample M90B is broad compared to that of (b) $\mathrm{m} 94 \mathrm{H}$, in which small sizes dominate. The extremes of the 1995 flow (c and d) fall within this range. The volume based median size $s_{\mathrm{v}}$ may be read from (e).

extrusion. The observed range in $\phi$ and $N_{\mathrm{A}}$ among all of the dome samples is indicated by the shaded area in Fig. 9b, a similar plot of textures in pyroclastic material generated by the November 1994 collapse.
Although the range in $\phi$ displayed by this material is greater than that represented by the dome material, $N_{\mathrm{A}}$ varies less. There appears to be no significant difference in either characteristic between pyroclastic flow, 


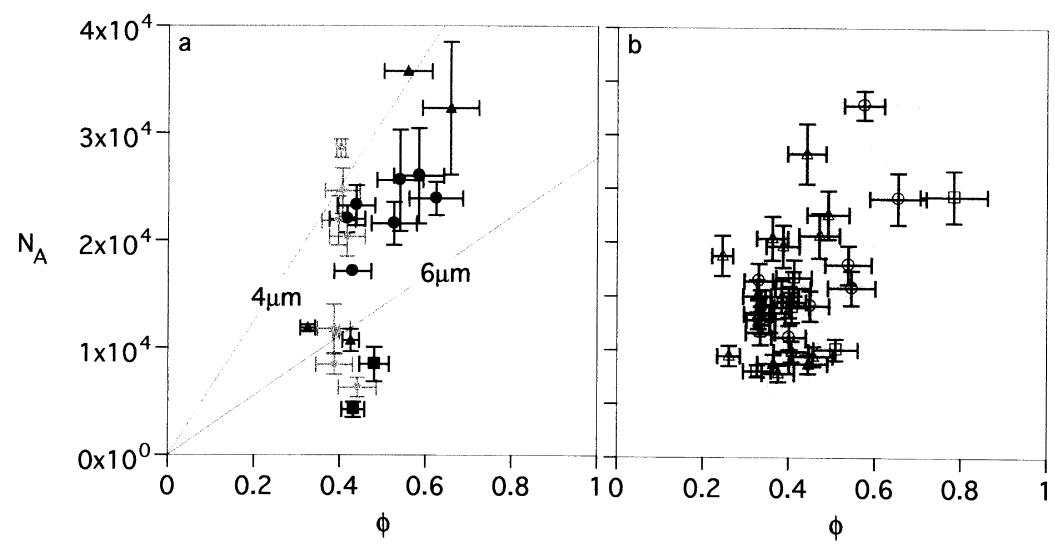

Fig. 9. Microlite $\phi$ vs. $N_{\mathrm{A}}$ in (a) Merapi domes and (b) pyroclastic material from the 1994 collapse. Data are sample averages. Error bars represent one standard deviation. (a) black squares $=1986-88$ dome lava; dark gray circles $=1992-93$ dome; medium gray triangles $=1994$ dome; light gray diamonds $=1995$ dome. The 1995 dome samples show constant $\phi$, and $N_{\mathrm{A}} \mathrm{s}$ that increase with distance from the vent. (b) squares $=$ pyroclastic flow; circles $=$ surge; triangles $=$ airfall.

surge, and airfall deposit types. In fact, most of the samples cluster at $\phi=0.40$ and $N_{\mathrm{A}} \sim 14000 \mathrm{~mm}^{-2}$. While this value of $\phi$ is also typical of dome material, the $N_{\mathrm{A}}$ value is low with respect to most dome samples.

A comparison of the microlite textures of 1994 pyroclastic material with both the 1994 dome, which collapsed to form it, and the 1995 dome, which immediately succeeded it (see Table 4, Fig. 9), allows assessment of the extent to which new material from the upper part of the conduit vs. the older 1994 dome material was involved in the November 1994 collapse. Although there is a larger range in $\phi(0.25-0.78)$ among the pyroclastic grains than in either dome (0.33-0.66 and 0.39-0.42, respectively), the collapse material prescribes a range in $N_{\mathrm{A}}(\sim 8000$ to $\sim 33000 \mathrm{~mm}^{-2}$ ) which is more similar to the 1994 dome $(\sim 11000$ to $\sim 35000)$ than that of 1995 ( $\sim 6000$ to $\sim 29000)$. However, the distribution of $N_{\mathrm{A}}$ values is different between the 1994 dome and the pyroclastic material. Two thirds of the pyroclastic grains have $N_{\mathrm{A}}$ less than the average value for the 1994 dome, and $20 \%$ of the pyroclastic grains fall below the minimum $N_{\mathrm{A}}$ for this dome $\left(\sim 11000 \mathrm{~mm}^{-2}\right)$. While 1995 dome samples extend to lower values of NA, and consequently may appear to more closely match the textural character of the pyroclastic material, the low values of $N_{\mathrm{A}}$ are observed in the 1995 dome exclusively in the proximal, or latest-erupted, material, and are therefore unlikely to be related to the material generated during the collapse. The small number of 1994 dome samples analyzed and uncertainty about whether the pyroclastic grains examined are representative of the deposits prevents a robust statistical comparison. Qualitatively, however, the microlite texture of the pyroclastic material appears to be more similar to that of the 1994 dome than that of the 1995 dome. Specifically, the pyroclastic material closely resembles dome samples M00X and m94G, blocks that toppled from the 1994 dome onto a shelf near the Gendol solfatara field prior to the collapse event. In summary, on the basis of textural considerations, material involved in the November 22, 1994 collapse is thought to be composed primarily of the existing 1994 dome. The relationship between effusive flux and $N_{\mathrm{A}}$ with respect to collapse events is explored in a later section.

\section{Discussion}

During ascent, highly crystalline Merapi magmas develop from having solid volume fractions of 0.300.50 (phenocrysts) up to $\sim 0.75$ after the growth of microlites. The highly evolved nature of melt within these andesite magmas at the time of eruption is interesting petrologically in terms of crystal fractionation 
and changing compositions of liquidus phases, but also in light of eruptive parameters such as changing magmatic $\mathrm{H}_{2} \mathrm{O}$ content and rheology. As decompression drives volatile exsolution, rates of degassing and resultant microlite crystallization may be governed by magma ascent rate. Since dome magmas appear at the surface variously populated with microlites, groundmass crystallization appears to occur syn-eruptively. Consequently, the history of changing conduit conditions, chiefly $\mathrm{H}_{2} \mathrm{O}$ content, during ascent may be preserved in the groundmass textures of quenched magma. For example, feldspar microlite compositions may be used to examine changes in dissolved $\mathrm{H}_{2} \mathrm{O}$ content, and crystal population densities may distinguish variable rates of undercooling experienced by magmas during ascent.

\subsection{Highly evolved andesites}

Merapi andesites contained high-silica liquids prior to their ascent to the surface due to high phenocryst contents. Calculation of glass composition prior to microlite crystallization by mass balance assuming $35 \%$ phenocrysts (consisting of $23 \%$ plagioclase, $8 \%$ clinopyroxene, $2 \%$ orthopyroxene, and $4 \%$ oxides) and typical bulk and phase compositions (del Marmol, 1989) yields an estimated liquid composition with $65 \mathrm{wt} . \% \mathrm{SiO}_{2}$. Since microlite crystallization further increases the silica content of the liquid, the observed variations in glass composition among pyroclastic tephras (Table 2) probably result from differing microlite contents (Fig. 10). For example, a simple mass balance calculation of $\mathrm{SiO}_{2}, \mathrm{Al}_{2} \mathrm{O}_{3}, \mathrm{CaO}$, $\mathrm{K}_{2} \mathrm{O}$ and $\mathrm{Na}_{2} \mathrm{O}$ shows that crystallization of less than $15 \%$ of the liquid can account for the difference in glass composition between $\mathrm{M} 81 \mathrm{~B}\left(66 \% \mathrm{SiO}_{2}\right)$ and a typical 1995 dome glass $\left(75 \% \mathrm{SiO}_{2}\right)$. A similar difference in microlite crystallinity is observed directly from SEM imaging of these samples, supporting the idea that bulk crystallization causes these variations in glass composition, rather than magma mixing (as suggested by Boudon et al. (1993) for 1984 nuée material). The abundance of microlites may also explain the difference in glass compositions in the "light" and "dark" material recognized in 1984 dome collapse material by Berthommier (1990) and Boudon et al. (1993). These authors report that the two types have nearly identical bulk compositions,

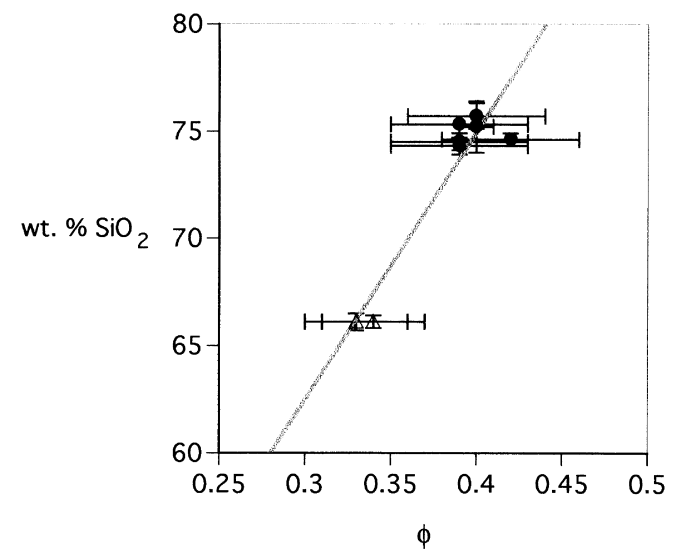

Fig. 10. Plot of groundmass crystallinity $(\phi)$ vs. wt. $\% \mathrm{SiO}_{2}$ for 1995 dome samples (filled circles) and airfall tephra from the 1994 dome collapse (open triangles). The linear relationship (wt.\% $\mathrm{SiO}_{2}=$ 124.4 $\left.(\phi+25.15) ; \mathrm{R}^{2}=0.88\right)$ between $\mathrm{SiO}_{2}$ content and $\phi$ demonstrates that that the dome and airfall liquids may be related by crystal fractionation.

but have glass compositions that differ in $\mathrm{SiO}_{2}$ by 3-7\% (Berthommier, 1990; Boudon et al., 1993). Mass balance indicates that these differences can be accounted for by feldspar crystallization from the "light" liquid of 8-30\% to produce the composition of the "dark" liquid.

\subsection{Implications of feldspar compositions for degassing}

The correlation between microlite size and core composition (Fig. 6) suggests that as crystallization progressed, the equilibrium feldspar composition changed due to the evolving liquid composition. Compositions of plagioclase cores are consistent with low degrees of undercooling, produced either by exsolution of $\mathrm{H}_{2} \mathrm{O}$ or by a drop in temperature. However, the crystallization of alkali feldspar rims requires the crystallization path to cross the two feldspar + liquid curve from the plagioclase + liquid $(\mathrm{Pl}+\mathrm{L})$ to alkali feldspar + liquid $(\mathrm{Af}+\mathrm{L})$ fields (Nekvasil and Lindsley, 1990; Nekvasil, 1992). Furthermore, solvus calculations at $0.1 \mathrm{MPa}$ using the feldspar solution modeling program SOLVCALC (Shaoxiong and Nekvasil, 1994) indicate that the core-rim compositions are not equilibrium pairs. Together with the observation that alkali feldspar 
mantles plagioclase and not the reverse, these calculations support the interpretation that core to rim crystallization is sequential rather than the result of a peritectic reaction of plagioclase and liquid to form alkali feldspar. Instead of simple cooling, the transition from plagioclase to alkali compositions is consistent with a change in the position of the two feldspar curve induced by degassing (Nekvasil, 1992). A possible interpretation of these data is that the liquid initially lay in the $\mathrm{Pl}+\mathrm{L}$ field, and crystallization followed an equilibrium path down-temperature. After degassing and a reduction in the activity of $\mathrm{H}_{2} \mathrm{O}$ in the liquid, the position of the two feldspar + liquid curve moved toward anorthite. The liquid was then located within the cotectic-like region of the Af $+\mathrm{L}$ field, and crystallization of alkali feldspar commenced at the edges of plagioclase cores.

Many of the crystals analyzed have rim compositions near $\mathrm{Ab}_{53} \mathrm{An}_{5} \mathrm{Or}_{42}$ (Figs. 7 and 11). It is possible that this composition represents the new equilibrium feldspar composition given the observed liquid composition at the temperature and pressure in the shallow conduit. Alternatively, the compositional homogeneity suggests that the crystallizing feldspar composition stabilized, perhaps as the liquid evolved to a pseudo-eutectic composition. If so, the high $\mathrm{SiO}_{2}$ content (74 wt.\%) would require quartz as a liquidus phase. The fact that quartz was not observed as a microlite (or phenocryst) phase may indicate that it could not precipitate due to sluggish kinetics of the highly evolved, de-watered system. A nucleation time lag (Naney and Swanson, 1980) for quartz which effectively caps crystallization at $\sim 0.75$ and fixes liquids at rhyolitic compositions may also define the undercooling conditions experienced by effusively erupted andesites. For example, the extrusion rate $\left(0.14 \mathrm{~m}^{3} \mathrm{~s}^{-1}\right)$, bulk and liquid compositions $(\sim 60$ and $\sim 73-78$ wt. $\% \mathrm{SiO}_{2}$, respectively), and estimated total crystal volume fraction (0.70) of the 1990-92 andesitic dome of Galeras volcano, Colombia, are comparable to those observed at Merapi (Calvache and Williams, 1997).

All of the feldspar data from this study, plus data from Boudon et al. (1993) and Bardintzeff (1984), are plotted in Fig. 11 with isothermal sections of the dry ternary feldspar solvus calculated by Solvcalc (Shaoxiong and Nekvasil, 1994) using the solution model of Elkins and Grove (1990). The position of the dry solvus is not sensitive to pressures corresponding to the expected depth range of degassing in the conduit (0-3 km; Kavalieris, 1994). Thus, depth is a factor controlling feldspar composition only insofar as $\mathrm{H}_{2} \mathrm{O}$ content varies with depth. The location of analyses with respect to the dry solvus does not imply that crystallization occurred at different temperatures, i.e. in response to cooling. Indeed, the alkali feldspar compositions appear to represent higher temperatures than the plagioclase compositions, the reverse of the evolution expected from cooling-induced crystallization. An hypothesis consistent with these observations and the degassing process implied by the core-rim pairs (described above) is that changes in the activity of $\mathrm{H}_{2} \mathrm{O}$ affected the position of the liquidus. We suggest that the liquidus temperature was lower during crystallization of plagioclase, so that the plagioclase compositions indicate artificially low temperatures with respect to the dry solvus shown. Degassing raised the liquidus temperature and relocated the position of the two feldspar + liquid curve, resulting in alkali feldspar crystallization at a higher apparent temperature.

We may now consider the feldspar compositions from this and other studies in the context of eruptive parameters using the above inferences about degassing. All of the domes and most of the pyroclastic-collapse material examined in this study are characterized by a highly crystalline groundmass and feldspar microlites with alkali feldspar rims, suggesting that degassing-induced crystallization is a common process in effusive eruptions at Merapi. Microlites and phenocryst rims observed in blocks deposited by recent nuées ardentes (Bardintzeff, 1984) have compositions similar to the dome and pyroclastic flow material from the 1994 collapse. The observations that some of the airfall grains from the 1994 collapse have microlites that lack these alkali feldspar rims, had less evolved liquid compositions, and vesiculated during dome collapse are all consistent with the interpretation that some of the magma involved in the collapse was less degassed than typical dome material. Characteristics of a 1984 nuée ardente deposit also point toward variably degassed magma involved in dome collapse. Based on high An contents of phenocryst rims and microlites (Fig. 11) and the presence of highly vesicular material, Boudon et al. (1993) suggest that liquid in the interior of the dome 

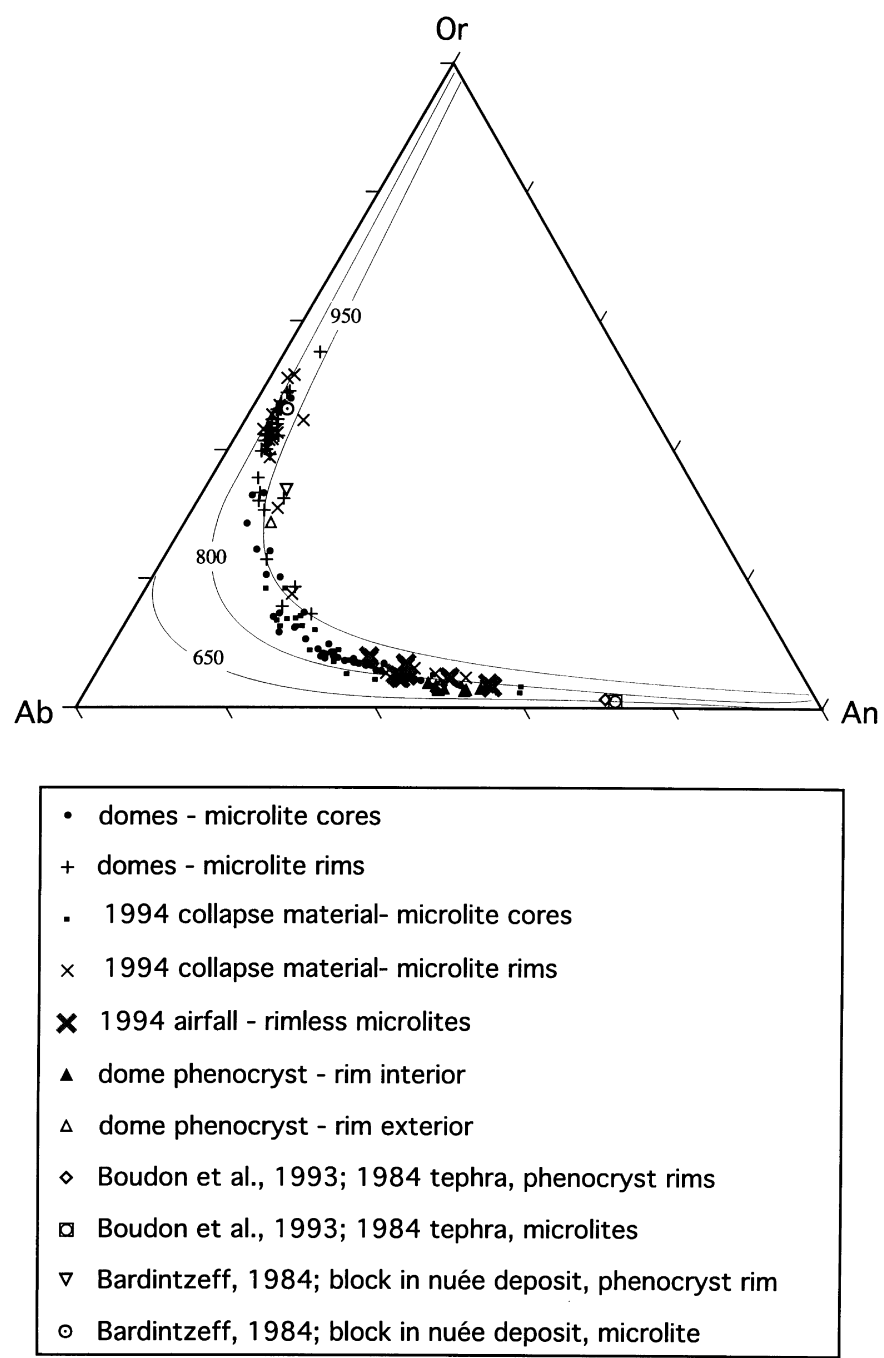

Fig. 11. Isothermal sections of the dry ternary solidus with data from this and other studies. Since they appear to represent different temperatures, crystallization of alkali feldspar rims on plagioclase cores probably results from changing activity of $\mathrm{H}_{2} \mathrm{O}$ in the liquid. A component of tephra from the 1984 (Boudon et al., 1993) and 1994 (this study) collapses lack alkali feldspar rims. These magmas may not have undergone extensive degassing and high degrees of undercooling.

or at the top of the conduit was not fully degassed at the time of collapse. The supposition that degassing occurs at shallow conduit levels is not surprising in the framework of observations of other volcanic systems (Cashman, 1992; Nakada et al., 1995; Calvache and Williams, 1997) and current degassing models (Woods and Koyaguchi, 1994; Barclay et al., 1995; Sparks, 1997), but the implication that a partly-liquid magma is tapped during collapse events at Merapi may be informative in the context of understanding mechanisms of dome failure.

In summary feldspar composition appears to be a sensitive indicator of changes in magmatic $\mathrm{H}_{2} \mathrm{O}$ content. Experimental calibration of undercooling and composition, including the effect of degassing on the position of the two feldspar + liquid curve with respect to Merapi lavas, could provide quantitative means to assess the degassing process in prehistoric as well as current eruptions. A closer 
examination of feldspar microlite compositions from events which span the complete range of eruptive styles exhibited by Merapi may provide critical information about the role of degassing in determining eruptive mechanism, and as a factor influencing the magnitude and/or frequency of collapse.

\subsection{Conditions of microlite nucleation and growth}

Recent textural analyses of volcanic lavas have involved interpretation of crystal size distributions (CSDs) to determine rates of crystal nucleation and growth (Cashman and Marsh, 1988; Cashman, 1992; Armienti et al., 1994; Higgins, 1996a,b; Peterson, 1996; Sharp et al., 1996). However, without an estimate of the duration of the crystallization interval necessary to extract rate information, we find the simple parameters $N_{\mathrm{A}}$ and $\phi$ useful in the assessment of crystallization parameters. If the system has time to compositionally equilibrate following $\mathrm{H}_{2} \mathrm{O}$ exsolution, $\phi$ gives an indication of the overall magnitude of the increase in liquidus temperature resulting from degassing $(\Delta \phi)$. Over short time periods, $\phi$ may reflect kinetic limitations to crystal nucleation and growth. In contrast, $N_{\mathrm{A}}$ reflects conditions of nucleation, and indicates the rate and degree of initial supersaturation. Rapid ascent and degassing, for example, will result in a relatively large instantaneous undercooling and a correspondingly high rate of crystal nucleation. A slower rate of gas loss will produce less rapid changes in $\Delta T$ and thus a lower nucleation rate. Final crystal textures are therefore an integration of both nucleation and growth processes.

Fields delimited in $\phi-N_{\mathrm{A}}$ space characterize the relative influence of these processes (Fig. 9). The observations that $N_{\mathrm{A}}$ varies by nearly one order of magnitude and that microlite size decreases with increasing $N_{\mathrm{A}}$ indicate that the initial nucleation rate must have been critical to the development of the observed texture. However, the high microlite crystallinity $(0.40-0.50)$ ultimately reached in these rocks suggests that nucleation was not the dominant process by which microlite content increased throughout the crystallization interval. Furthermore, the trend of $\phi-\mathrm{N}_{\mathrm{A}}$ data does not intersect the origin as has been observed in nucleationdominated systems (e.g. Mt. Pinatubo dacite; Hammer et al., 1999).
Several crystallization paths through $\phi-N_{\mathrm{A}}$ space are schematically illustrated in Fig. 12a. Initially, crystallization increases primarily by nucleation (beginnings of paths 1 and 2A,B). Under conditions of rapid ascent, nucleation may continue to control the system throughout the crystallization interval (e.g. path 1) due to high rates of continued undercooling (Hammer et al., in review). However, if the degree of undercooling decreases over time, perhaps because the system approaches equilibrium, growth of existing crystals prevails over nucleation as the dominant crystallization mechanism (paths 2A and 2B). Departure from the nucleation-dominated curve (path 1) may occur at any point during crystallization, so that a range of $N_{\mathrm{A}}$ values are preserved (shaded region). Given the relatively low rates of undercooling experienced by slow-ascending dome lavas, $N_{\mathrm{A}}$ and undercooling may be linearly related over the crystallization conditions within the Merapi conduit. A schematic version of the $\Delta T$-nucleation rate curves defined experimentally for rhyolites (Swanson, 1977) is shown in Fig. 12b. At very low degrees of undercooling, there is a nucleation time-lag during which crystallization is suppressed. As undercooling increases to moderate levels, microlites begin to nucleate at a rate proportional to the driving force, producing textures of increasing $N_{\mathrm{A}}$ (dashed parts of curve). However, at high degrees of undercooling, kinetic constraints may reverse the trend in $N_{\mathrm{A}}$ with $\Delta T$, so that exceptionally high undercoolings common to explosive eruptive styles may produce any of a wide range in $N_{\mathrm{A}}$ values, including microlite-free material.

Examination of the Merapi textures (Fig. 9) suggests that following an initial nucleation-dominated period, crystal growth must have superseded nucleation as the primary process by which crystallinity increased. This is especially clear in the 1995 dome, in which $\phi$ is essentially constant despite a large range of $N_{\mathrm{A}}$. In summary, these data suggest that initial nucleation rates varied considerably although the final conditions achieved by the magmas remained approximately constant. Although most of the crystallization interval was probably dominated by growth rather than nucleation, $N_{\mathrm{A}}$ established in the early stages of textural development was responsible for the differences in final microlite size and spatial distribution. 

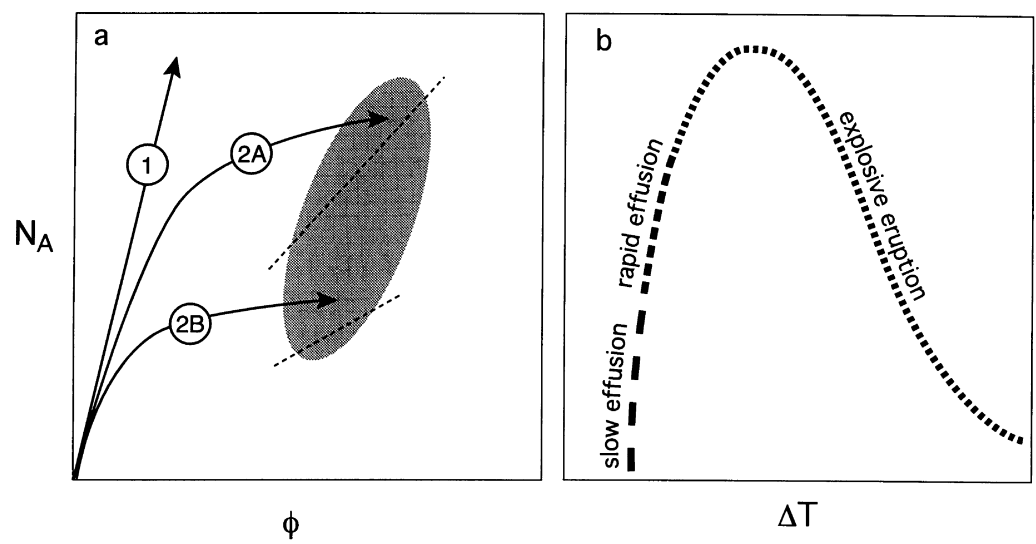

Fig. 12. (a) Schematic illustration of crystallization paths experienced by erupting lavas. Merapi dome textures reflect initial nucleationdominated crystallization (path 1) followed by a growth-dominated regime (paths $2 \mathrm{~A}$ and $2 \mathrm{~B}$ ). A decrease in ascent rate during emplacement may promote a change from path $2 \mathrm{~A}$ to $2 \mathrm{~B}$, resulting in the observed decrease in $N_{\mathrm{A}}$ among the 1995 samples with proximity to the vent. Data field (shaded area) crosses dotted lines representing constant ratios of $N_{\mathrm{A}}$ to $\phi$ (constant size). (b) Hypothetical curve modified from Swanson (1977) relates $N_{\mathrm{A}}$ and $\Delta T$, showing that over low-degrees of undercooling (long dashed-curve), microlite population density is proportional to the rate of undercooling (and possibly ascent). As $\Delta T$ increases, rates of nucleation peak and then decline, resulting in a much larger potential range of textures produced by explosive eruptions (short dashed-curve).

\subsection{Textural implications for extrusion rate during dome emplacement}

In the spatially constrained 1995 dome samples, $N_{\mathrm{A}}$ and $\mathrm{SA} / V$ increase with distance from the vent, while microlite size decreases (Table 5, Fig. 13). These trends indicate that nucleation and growth rates were higher in the distal, earlier-erupted magma relative to the vent-proximal material which was emplaced later. It is possible that elevated rates of feldspar supersaturation, and therefore microlite nucleation, correspond to a higher rate of ascent through the conduit. Assuming that degassing occurs as the magma rises, a decrease in ascent rate as the dome extruded would produce a decrease in the degree of undercooling. Several independent assessments of magmatic fluxes are available for the interval represented by these samples, and demonstrate the degree to which $N_{\mathrm{A}}$ is sensitive to changes in effusion rate.

Samples from the 1984-90 dome are believed to represent lavas produced in the period of late 198688 , characterized by an extrusion rate of about $0.05 \mathrm{~m}^{3} \mathrm{~s}^{-1}$. The average $N_{\mathrm{A}}$ for the two samples analyzed is $6352 \mathrm{~mm}^{-2}$. The best- constrained 1992 dome sample, M92A $\left(N_{\mathrm{A}}=21959 \mathrm{~mm}^{-2}\right)$, was produced during a period of significantly higher rate of effusion, $0.23 \mathrm{~m}^{3} \mathrm{~s}^{-1} . N_{\mathrm{A}}$ values of 1994 dome samples appear to be bimodally distributed, with peaks at 8058 and $32808 \mathrm{~mm}^{-2}$, and are compared with the lowest and highest average eruption rates calculated for the 1994 dome, $\left(0.08\right.$ and $0.32 \mathrm{~m}^{3} \mathrm{~s}^{-1}$; Ratdomopurbo, 1995; unpubl. data). These data, plotted in Fig. 14, yield a surprisingly linear trend, given the limitations in matching samples to effusion rate. A regression line of $N_{\mathrm{A}}=95637 Q+$ $2145\left(R^{2}=0.980\right)$ fits these data. Applying the relation to other 1992-93 dome samples using measured

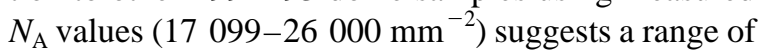
fluxes between 0.16 and $0.25 \mathrm{~m}^{3} \mathrm{~s}^{-1}$, with the mean $N_{\mathrm{A}}$ value $\left(22888 \mathrm{~mm}^{-2}\right)$ yielding a mean flux of $0.22 \mathrm{~m}^{3} \mathrm{~s}^{-1}$. This result suggests that all the 199293 samples analyzed are comparable in age to M92A, forming in mid-1992 rather than in 1993. (After November 1992 the flux dropped to $\sim 0.08 \mathrm{~m}^{3} \mathrm{~s}^{-1}$ and would presumably have generated microlite textures having $N_{\mathrm{A}}$ values less than $\sim 10000 \mathrm{~mm}^{-2}$.) Application of the relation to the $N_{\mathrm{A}}$ values of temporally constrained 1995 dome samples $\left(6305-28563 \mathrm{~mm}^{-2}\right)$ suggests that eruption rate decreased from 0.28 to $0.04 \mathrm{~m}^{3} \mathrm{~s}^{-1}$ during extrusion.

Factors controlling extrusion rate of the Merapi dome include changing geometry of the dome itself, and fluctuations in the magma supply rate from a deep 


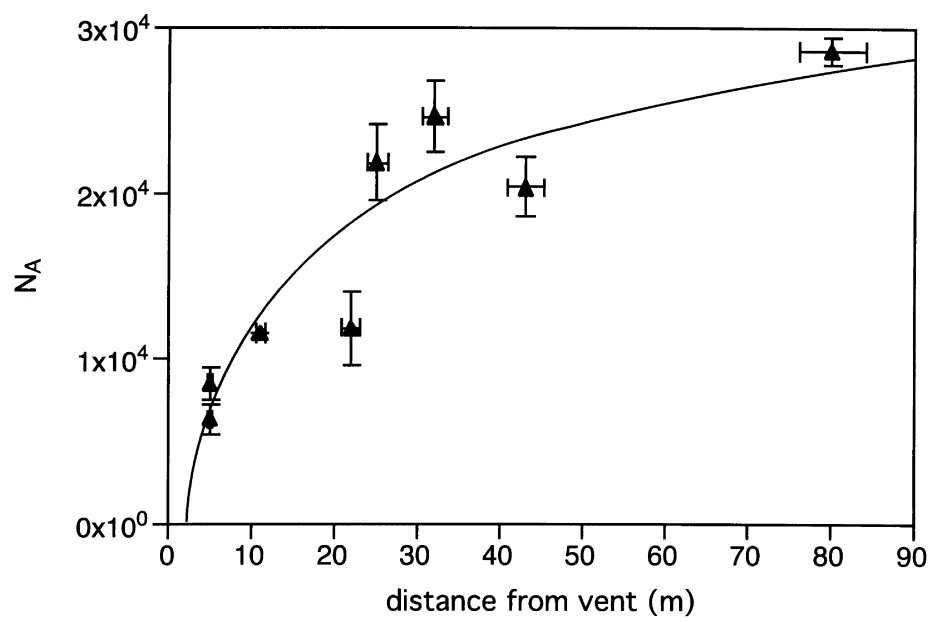

Fig. 13. Microlite $N_{\mathrm{A}}$ values determined for 1995 dome samples are plotted as a function of distance from the vent. $N_{\mathrm{A}}$ appears to increase rapidly initially, then gradually with distance, suggesting that nucleation rate was high early during extrusion and then decreased towards the end of the time period represented by these samples. The data are fit with a logarithmic function $\left(N_{\mathrm{A}}=7547 \ln (\right.$ distance $\left.) ; R^{2}=0.84\right)$.

reservoir. Changes in the mass and shape of the dome may result from time-averaged effusion rate history (Griffiths and Fink, 1993; Fink and Bridges, 1995) and instabilities (collapse events), and partly control eruptive parameters (Stasiuk et al., 1993; Nakada et al., 1995; Stasiuk and Jaupart, 1997). In the first consideration, ascent rate would increase in response to increased pressure gradient following dome collapse. Pressure release during collapse could also drive explosive fragmentation of solidified or partlysolidified material (Alidibirov and Dingwell, 1996). In the latter, weight of a rising dome over a conduit would increasingly hinder ascent and suppress effusive flux.

An additional, complicating factor involves the effects of degassing (including magma pressurization, volume change and viscosity increase) which may cause effusion rate to be high following dome collapse or to decrease over time during emplacement. Degassing under any conditions except a completely open system (such as incomplete or multi-step open system degassing; Anderson et al., 1995; Taylor, 1991) will result in pressurization of the conduit. Sudden release of this pressure due to dome collapse could induce a temporarily elevation of effusive flux. On the other hand, exsolution of $\mathrm{H}_{2} \mathrm{O}$ from the liquid increases its viscosity (Shaw, 1972; Hess and Dingwell, 1996; Richet et al., 1996). If accompanied by microlite crystallization, the increase in $\mathrm{SiO}_{2}$ content of the liquid magnifies the viscosity increase (Shaw, 1972). For example, the increase in viscosity resulting from degassing and crystallizing a $66 \mathrm{wt} . \%$ $\mathrm{SiO}_{2}$ liquid with 2 wt. $\% \mathrm{H}_{2} \mathrm{O}$ to produce a 75 wt. $\%$ $\mathrm{SiO}_{2}$ liquid with 0.1 wt. $\% \mathrm{H}_{2} \mathrm{O}$ (the observed range this study), is three orders of magnitude $\left(10^{5.8}\right.$ $10^{8.8} \mathrm{~Pa} \mathrm{~s}$ ). Bulk viscosity will be further increased by the addition of crystals to the magma from degassing-induced crystallization. Merapi magmas contain high volume fractions $(0.3-0.5)$ of phenocrysts prior to groundmass crystallization. The growth of microlites increases the total crystal content beyond the empirically-defined maximum particle concentration, 0.60 (Marsh, 1981), and creates a large yield strength. The effect of these profound rheological changes within the upper conduit would be to decrease ascent rate over time as $\mathrm{H}_{2} \mathrm{O}$ exsolution and microlite crystallization progresses. When and ascent rate decreases throughout dome emplacement, as in the 1995 effusive period, then the surface processes described above may control effusive flux at Merapi. On the other hand, if ascent rates do not decrease over time, near-surface geometric and degassing effects may be subordinate to short term fluctuations in overpressure from the magma chamber in controlling rates of magma ascent, degassing and crystallization.

Further information about controls on dome 


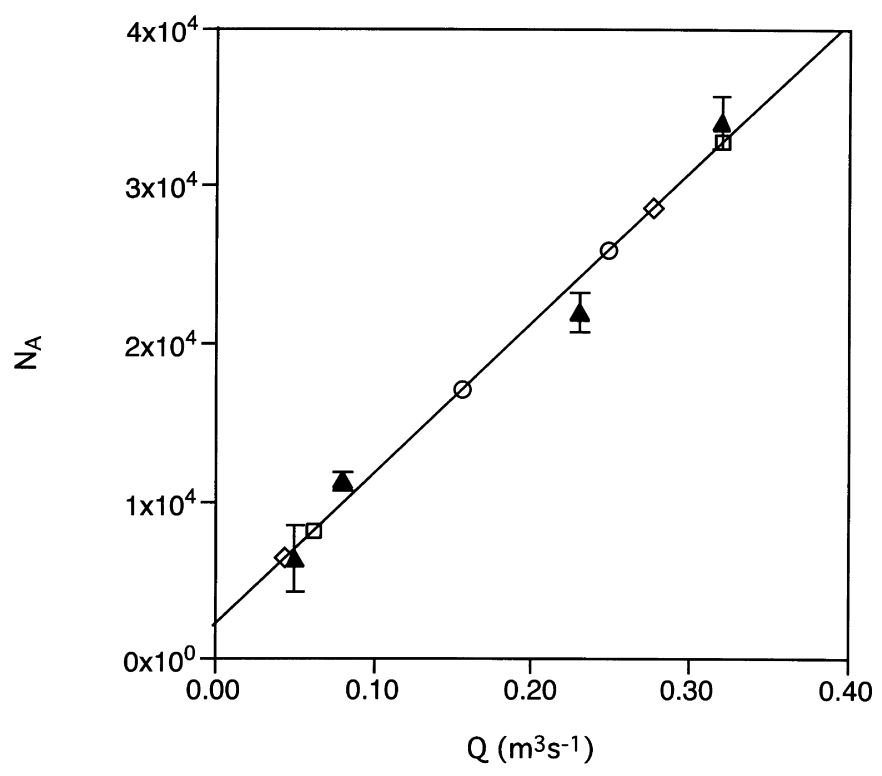

Fig. 14. A relationship between $N_{\mathrm{A}}$ and effusive flux $Q$, is determined using data from Tables 1 and 4 . These data are plotted as filled triangles. $N_{\mathrm{A}}$ values consisting of the average of the M90B and M90E, M92A, and averages of both modes of the bimodal 1994 data (M00X, m94G and $\mathrm{m} 94 \mathrm{P}, \mathrm{m} 94 \mathrm{H})$ were compared with estimated fluxes for these effusive periods to obtain the relation: $N_{\mathrm{A}}=95637(Q+2145) ; R^{2}=0.98$. Effusive fluxes for remaining extrusion periods were calculated by applying this relationship to endmember $N_{\mathrm{A}}$ values. Extrusion rates represented by the textures of 1992-93 dome (open circles), 1994 pyroclastic (open squares), and 1995 dome (open diamonds) material are similar to ranges spanned by the 1986-88 and 1994 domes.

extrusion are provided by dome interior samples from the 1994 pyroclastic deposits. The fact that highly crystalline, incipiently devitrified material (Fig. 4b) was identified within the 1994 pyroclastic material implies that portions of the hot dome interior were below the glass transition temperature. However, most grains resemble the quenched surface dome lavas in having pristine glass and distinct microlites. Effusive fluxes consistent with the full $N_{\mathrm{A}}$ range for non-devitrified grains (Table 4) encompass a large range $\left(0.06-0.32 \mathrm{~m}^{3} \mathrm{~s}^{-1}\right)$, although the majority of the grains indicate effusion rates around $0.1 \mathrm{~m}^{3} \mathrm{~s}^{-1}$. This is consistent with the idea that the lava in this part of the collapsed dome was effused early in 1994, when flux was low. Since the 1994 failure appears to have occurred during a period of relatively slow extrusion, and no clear precursors have been identified, the mechanism for collapse was probably gravitational. However, the presence of lower-crystallinity and vesicular clasts suggests that less degassed super-solidus portions of the dome or conduit were involved in the collapse as well, albeit to a limited volumetric extent.
Our results complement previous observations that degassing-induced crystallization is common to effusive volcanic systems (Westrich et al., 1988; Swanson et al., 1989; Stevenson et al., 1994b; Geschwind and Rutherford, 1995; Nakada and Motomura, 1995; Wolf and Eichelberger, 1997), and indicate that quantitative estimates of eruptive parameters may be extracted from detailed textural measurements. Crystal nucleation and growth conditions are manifested in textures of dome rocks, and preserve a record of change in magmatic volatile contents during ascent. Future studies of this kind would be strengthened by spatially constrained sample sets from several effusive periods correlated with gas and seismic monitoring as well as direct observations of dome growth rate. Once calibrated, the microlite characterization techniques introduced here may provide a tool for investigating patterns of dome growth rate and failure events in the context of physical and chemical eruptive processes. 


\section{Acknowledgements}

This work was supported by National Science Foundation grants BSC 8904990, EAR-9106134, -917296, and -9316739 to Voight and EAR-9418008 to Cashman. Images and compositional analyses were obtained using the JEOL JSM-6300V SEM and CAMECA SX-50 Electron Probe Microanalyzer in the Department of Geological Sciences at the University of Oregon, funded by grants from the W.M. Keck Foundation and the National Science Foundation. We are grateful to the Merapi Volcano Observatory and the Volcanological Survey of Indonesia for logistical help and hospitality. Reviews by Hana Nekvasil and Steve Anderson are sincerely appreciated. Special thanks to Kirby Young for sample collection assistance, translation of several French dissertations, and constructive discussions during preparation of this manuscript.

\section{Appendix A. Abbreviations used in text and figures}

a: Shortest microlite dimension $(\mu \mathrm{m})$

b: Intermediate microlite dimension $(\mu \mathrm{m})$

$b$ : Breadth; the minimum caliper diameter of a microlite $(\mu \mathrm{m})$

c: Longest microlite dimension $(\mu \mathrm{m})$; may be calculated two ways (see text)

$\phi$ : Fraction of groundmass consisting of feldspar microlites

I: The ratio of the intermediate to shortest microlite dimension; $I=\mathbf{b} / \mathbf{a}$

$k$ : Microlite shape factor; $\mathrm{k}=\mathrm{I} /\left(\mathrm{L}^{2}\right)$

$l$ : Length; the longest chord connecting any two points on the perimeter of a microlite $(\mu \mathrm{m})$

$L$ : The ratio of the longest to shortest microlite dimension; $L=\mathbf{c} / \mathbf{a}$

$N_{\mathrm{A}}$ : Number density; number of microlites per unit area $\left(\mathrm{mm}^{-2}\right)$

$n^{\circ}: y$-intercept of linear crystal size distribution (CSD)

$A_{\mathrm{R}}$ : Reference area; the portion of an image consisting of feldspar microlites and glass $\left(\mu \mathrm{m}^{2}\right)$

$A_{\mathrm{R} \phi}$ : Reference area used for $\phi$ calculation $\left(\mu \mathrm{m}^{2}\right)$

$A_{\mathrm{RNA}}$ : Reference area for $N_{\mathrm{A}}$ calculation $\left(\mu \mathrm{m}^{2}\right)$

SA: Microlite surface area; $\mathrm{SA}=2(\mathbf{a b}+\mathbf{a c}+\mathbf{b c})$

$S_{n}$ : Number-based mean size $(\mu \mathrm{m})$; computed as $\left[\left(\phi / N_{\mathrm{A}}\right)^{0.5} 10^{3}\right]$
$S_{\mathrm{v}}$ : Volume-based median size $(\mu \mathrm{m})$; measured using cumulative volume distribution of microlite size. See Fig. 7.

$Q$ : Effusive flux $\left(\mathrm{m}^{3} \mathrm{~s}^{-1}\right)$

$V$ : Microlite volume; $V=\mathbf{a b c}$

\section{References}

Abbot, R.J., 1978. Peritectic relations in the system An-Ab-OrQz- $\mathrm{H}_{2}$ O. Can. Mineral. 16, 245-256.

Abdurachman, E., Bourdier, J., Voight, B., Kelfoon, K., 2000. Nueés ardentes, of 22 November 1994 at Merapi Volcano, Indonesia. J. Volcanol. Geotherm. Res. 100, 345-361.

Alidibirov, M., Dingwell, D.B., 1996. Magma fragmentation by rapid decompression. Nature 380, 146-148.

Allard, P., Carbonnelle, J., Dajlevic, D., Metrich, N., Sabroux, J., 1995. The volatile source and magma degassing budget of Merapi volcano: evidence from high-temperature gas emissions and crystal melt inclusions. Merapi Decade Volcano Workshop, Yogyakarta, Indonesia, $66 \mathrm{pp}$.

Anderson, S., Fink, J., 1989. The development and distribution of surface textures at the Mount St. Helens dome. In: Fink, J. (Ed.), Lava Flows and Domes. Springer, New York, pp. 25-46.

Anderson, S., Fink, J., Rose, W., 1995. Mount St. Helens and Santiaguito lava domes: the effect of short-term eruption rate on surface texture and degassing processes. J. Volcanol. Geotherm. Res. 69, 105-116.

Armienti, P., Pareschi, M., Innocenti, F., Pompilio, M., 1994. Effects of magma storage and ascent on the kinetics of crystal growth. Contrib. Mineral. Petrol. 109, 431-449.

Bagdassarov, N., Dingwell, D., Wilding, M., 1996. Rhyolite magma degassing: an experimental study of melt vesiculation. Bull. Volcanol. 57, 587-601.

Barclay, J., Riley, D., Sparks, R., 1995. Analytical models for bubble growth during decompression of high viscosity magmas. Bull. Volcanol. 57, 422-431.

Bardintzeff, J., 1984. Merapi Volcano (Java Indonesia) and MerapiType Nuée Ardente. Bull. Volcanol. 47, 433-446.

Berthommier, P., 1990. Etude volcanologique du Merapi (CentreJava): Téphrostratigraphic et Chronologie-produits éruptifs. $\mathrm{PhD}$ thesis, Université Blaise Pascal, $216 \mathrm{pp}$.

Boudon, G., Camus, G., Gourgaud, A., Lajoie, J., 1993. The 1984 nuée-ardente deposits of Merapi volcano Central Java, Indonesia: stratigraphy, textural characteristics, and transport mechanisms. Bull. Volcanol. 55, 327-342.

Calvache, M., Williams, S., 1997. Emplacement and petrological evolution of the andesitic dome of Galeras volcano 1990-1992. J. Volcanol. Geotherm. Res. 77, 57-69.

Cashman, K., 1992. Groundmass crystallization of Mount St. Helens dacite, 1980-1986: a tool for interpreting shallow magmatic processes. Contrib. Mineral. Petrol. 109, 431-449.

Cashman, K., Marsh, B., 1988. Crystal size distribution (CSD) in rocks and the kinetics and dynamics of crystallization. Contrib. Mineral. Petrol. 99, 292-305. 
Chouet, B., 1996. Long-period volcano seismicity: its source and use in eruption forecasting. Nature 380, 309-316.

Corrigan, G., 1982. The crystal morphology of plagioclase feldspar produced during isothermal supercooling and constant rate cooling experiments. Mineral. Mag. 46 (341), 433-439.

Cruz, F., Chouet, B., 1997. Long-period events, the most characteristic seismicity accompanying the emplacement and extrusion of a lava dome in Galeras Volcano, Colombia, in 1991. J. Volcanol. Geotherm. Res. 77, 121-158.

del Marmol, M., 1989. The petrology and geochemistry of Merapi volcano, Central Java, Indonesia. PhD thesis, Johns Hopkins University, Baltimore, 383 pp.

Elkins, L., Grove, T., 1990. Ternary feldspar experiments and thermodynamic models. Am. Mineral. 75 (5-6), 544-559.

Fink, J., Bridges, N., 1995. Effects of eruption history and cooling rate on lava dome growth. Bull. Volcanol. 57, 229-239.

Fink, J., Kieffer, S., 1993. Estimate of pyroclastic flow velocities resulting from explosive decompression of lava domes. Nature $363,612-615$.

Fink, J., Anderson, S., Manley, C., 1992. Textural constraints on effusive silicic volcanism: beyond the permeable foam model. J. Geophys. Res. 97 (B6), 9073-9083.

Gardner, C.A., Cashman, K.V., Neal, C.A., 1998. Tephra-fall deposits from the 1992 eruption of Crater Peak, Alaska: implications of clast textures for eruptive processes. Bull. Volcanol. 59: 537-555.

Geschwind, C., Rutherford, M.J., 1995. Crystallization of microlites during magma ascent: the fluid mechanics of recent eruptions at Mount St. Helens. Bull. Volcanol. 57, 356-370.

Griffiths, R., Fink, J., 1993. Effects of surface cooling on the spreading of lava flows and domes. J. Fluid Mech. 252, 666-702.

Hammer, J., Cashman, K., Hoblitt, R., Newman, S., 1999. Degassing and microlite crystallization during pre-climactic events of the 1991 eruption of Mt. Pinatubo, Philippines. Bull. Volcanol. 60, 355-380.

Heiken, G., Wohletz, K., 1987. Tephra deposits associated with silicic domes and lava flows. Geol. Soc. Am. Spec. Pap. 212, $55-76$.

Hess, K.-U., Dingwell, D., 1996. Viscosities of hydrous leucogranitic melts: a non-Arrhenian model. Am. Mineral. 81, 1297-1300.

Higgins, M., 1994. Numerical modeling of crystal shapes in thin sections; estimation of crystal habit and true size. Am. Mineral. 79 (1-2), 113-119.

Higgins, M., 1996. Crystal size distributions and other quantitative textural measurements in lavas and tuff from Egmont volcano (Mt. Taranaki). N.Z. Bull. Volcanol. 58, 194-204.

Higgins, M., 1996. Magma dynamics beneath Kameni volcano Greece, as revealed by crystal size and shape measurements. J. Volcanol. Geotherm. Res. 70, 37-48.

Housh, T., Luhr, J., 1991. Plagioclase-melt equilibria in hydrous systems. Am. Mineral. 76, 477-492.

Kavalieris, I., 1994. High Au Ag, Mo, Pb, V and W content of fumarolic deposits at Merapi volcano, central Java, Indonesia. J. Geochem. Explor. 50, 479-491.

Klug, C., Cashman, K.V., 1994. Vesiculation of May 18, 1980, Mount St. Helens magma. Geology. 22: 468-472.
Le Guern, F., Gerlach, T., Nohl, A., 1982. Field gas chromatograph analyses of gases from a glowing dome at Merapi Volcano Java, Indonesia. J. Volcanol. Geotherm. Res. 14, 223-245.

Lofgren, G., 1974. Experimental study of plagioclase crystal morphology: isothermal crystallization. Am. J. Sci. 274, 243-273.

Marsh, B., 1981. On the crystallinity, probability of occurrence, and rheology of lava and magmas. Contrib. Mineral. Petrol. 78, 85-98.

Marsh, B., 1988. Crystal size distributions (CSD) in rocks and the kinetics and dynamics of crystallization I Theory. Contrib. Mineral. Petrol. 99, 277-291.

Nakada, S., 1993. Lava domes and pyroclastic flows of the 1991-1992 eruption at Unzen volcano. In: Yanagi, T., Okada, H., Ohta, T. (Eds.), Unzen Volcano: the 1990-1992 Eruption. Nishininippon and Kyushy University Press, pp. 56-66.

Nakada, S., Miyake, Y., Sato, H., Oshima, O., Fujinawa, A., 1995. Endogenous growth of dacite dome at Unzen volcano (Japan), 1993-1994. Geology 23 (2), 157-160.

Nakada, S., Motomura, Y., 1995. Manner of magma ascent at Unzen volcano (Japan). Geophys. Res. Lett. 22 (5), 567-570.

Naney, M., Swanson, S., 1980. The effect of Fe and Mg on crystallization in granitic systems. Am. J. Sci. 283, 993-1033.

Nekvasil, H., 1992. Ternary feldspar crystallization in hightemperature felsic magmas. Am. Mineral. 77, 592-604.

Nekvasil, H., Lindsley, D., 1990. Termination of the 2 feldspar + liquid curve in the system $\mathrm{Ab}-\mathrm{Or}-\mathrm{An}-\mathrm{H}_{2} \mathrm{O}$ at low $\mathrm{H}_{2} \mathrm{O}$ contents. Am. Mineral. 75, 1071-1079.

Newman, S., Epstein, S., Stolper, E., 1988. Water, carbon dioxide, and hydrogen isotopes in glasses from the ca. 1340 A.D. eruption of the Mono Craters, California: constraints on degassing phenomena and initial volatile content. J. Volcanol. Geotherm. Res. 35, 75-96.

Peccerillo, A., Taylor, S., 1976. Geochemistry of some calc-alkaline volcanic rocks from the Kastamonu area, Northern Turkey. Contrib. Mineral. Petrol. 58, 63-81.

Peterson, T., 1996. A refined technique for measuring crystal size distributions in thin section. Contrib. Mineral. Petrol. 124, 395-405.

Ratdomopurbo, A., 1995. Etude sismologique du volcan Merapi et Formation du dome de 1994. PhD thesis, Universite Joseph Fourier, Grenoble, 208 pp.

Richet, P., Lejeune, A., Hotlz, F., Roux, J., 1996. Water and the viscosity of andesite melts. Chem. Geol. 128, 185-197.

Rose, W., et al., 1988. Direct rate measurements of eruption plumes at Augustine volcano: a problem of scaling and uncontrolled variables. J. Geophys. Res. 93, 4485-4499.

Sadjiman, 1986. Peta situasi puncak Gunung Merapi. Direktorat Vulkanologi, Yogyakarta.

Shaoxiong, W., Nekvasil, H., 1994. Solvcalc: an interactive graphics program package for calculating the ternary feldspar solvus and for two-feldspar geothermometry. Comput. Geosci. $20,1025-1040$.

Sharp, T., Stevenson, R., Dingwell, D., 1996. Microlites and "nanolites" in rhyolitic glass: microstructural and chemical characterization. Bull. Volcanol. 57, 631-640. 
Shaw, H., 1972. Viscosities of magmatic silicate liquids: an empirical method of prediction. Am. J. Sci. 272, 870-889.

Siswowidjoyo, S., Suryo, I., Yokoyama, I., 1995. Magma eruption rates of Merapi volcano, Central Java, Indonesia during one century (1890-1992). Bull. Volcanol. 57, 111-116.

Smithsonian, 1995. GVN Bull. 2.

Sparks, R., 1997. Causes and consequences of pressurisation in lava dome eruptions. Earth Planet. Sci. Lett. 150, 177-189.

Stasiuk, M., Jaupart, C., 1997. Lava flow shapes and dimensions as reflections of magma system conditions. J. Volcanol. Geotherm. Res. 78, 31-50.

Stasiuk, M., Jaupart, C., Sparks, S., 1993. On the variation of flow rate in non-explosive lava eruptions. Earth Planet. Sci. Lett. 114, 505-516.

Stasiuk, M., Barclay, J., Carroll, M.R., Jaupart, C., Ratté, J.C., Sparks, R.S.J., Tait, S.R., 1996. Degassing during magma ascent in the Mule Creek vent (USA). Bull. Volcanol. 58, 117-130.

Stevenson, R., Briggs, R., Hodder, A., 1994. Physical volcanology and emplacement history of the Ben Lomond rhyolite lava flow Taupo Volcanic Centre, New Zealand. N.Z. J. Geol. Geophys. 37, 345-358.

Stevenson, R., Sharp, T., Dingwell, D., 1994. The role of microlites during the cooling and crystallization of rhyolitic melts. International Mineralogical Association, 16th general meeting. International Mineralogical Association, Pisa, Italy, 393 pp.

Stix, J., et al., 1993. A model of degassing at Galeras volcano, Colombia, 1988-1993. Geology 21, 963-967.

Stoiber, R., Malinconico, L., Williams, S., 1983. Use of the correlation spectrometer at volcanoes. In: Tazieff, H., Sabroux, J. (Eds.), Forecasting Volcanic Events. Elsevier, Amsterdam, pp. 425-444.

Sunagawa, I., 1984. Growth of crystals in nature. In: Sunagawa, I. (Ed.), Materials and Science of the Earth's Interior. Terra Scientific Publishing Company, Tokyo, pp. 63-105.
Swanson, S., 1977. Relation of nucleation and crystal-growth rate to the development of granitic textures. Am. Mineral. 62, 966978.

Swanson, S., Naney, M.H.R.W., Eichelberger, J., 1989. Crystallization history of Obsidian Dome Inyo Domes, California. Bull. Volcanol. 51, 161-176.

Symonds, R., Rose, W., Reed, M., Lichte, F., Finnegan, D., 1987. Volatilization, transport and sublimation of metallic and nonmetallic elements in high temperature gases at Merapi Volcano, Indonesia, Geochim. Cosmochim. Acta 51, 2083-2101.

Taylor, B., 1991. Degassing of Obsidian Dome rhyolite, Inyo volcanic chain, California. In: Taylor, H.J., O’Neil, J., Kaplan, I. (Eds.), Stable Isotope Geochemistry: a Tribute to Samuel Epstein. The Geochemical Society, San Antonio, pp. 339-353.

Taylor, B., Eichelberger, J., Westrich, H., 1983. Hydrogen isotopic evidence of rhyolitic degassing during shallow intrusion and eruption. Nature 306, 541-545.

van Bemmelen, R., 1949. The geology of Indonesia. Martinus Nijhoff, The Hague, pp. 192-207.

Westrich, H.R., Stockman, H.W., Eichelberger, J.C., 1988. Degassing of rhyolitic magma during ascent and emplacement. J. Geophys. Res. 93 (B6), 6503-6511.

Wolf, K., Eichelberger, J., 1997. Syneruptive mixing, degassing, and crystallization at Redoubt Volcano, eruption of December 1989 to May 1990. J. Volcanol. Geotherm. Res. 75, 19-37.

Woods, A.W., Koyaguchi, T., 1994. Transitions between explosive and effusive eruptions of silicic magmas. Nature 370, 641-644.

Zapata, G.J., Calvache, V.M.L., Cortés, J.G.P, Fischer, T.P., Garzon, V.G., Gómez, M.D., Narváez, M.L., Ordóñez, V.M., Ortega, E.A., Stix, J., Torres, C.R., Williams, S.N., 1997. $\mathrm{SO}_{2}$ fluxes from Galeras Volcano, Colombia, 1989-1995: progressive degassing and conduit obstruction of a decade volcano. J. Volcanol. Geotherm. Res. 77, 195-208. 